\title{
Do free trade agreements affect tariffs of non-member countries? A theoretical and empirical investigation
}

\author{
Kamal Saggi*, Andrey Stoyanov ${ }^{\dagger}$ Halis Murat Yildiz ${ }^{\ddagger}$
}

\begin{abstract}
In this paper, we investigate both theoretically and empirically the effects of free trade agreements (FTAs) on the tariffs of non-member countries. Our theoretical framework draws on the comparative advantage based trade model of Horn, Maggi, and Staiger (2010). In this model, since marginal costs of production are increasing with output, if a few countries form an FTA and start trading more with each other, they simultaneously become less willing to export to rest of the world - a phenomenon we call external trade diversion. Such diversion reduces the ability and the incentive of non-member countries to manipulate their terms of trade, a mechanism that induces them to lower their tariffs on FTA members. We provide an empirical confirmation of this insight using industrylevel bilateral trade data for 192 importing and 253 exporting countries, along with the information on all FTAs formed in the world during 1989-2011. Our analysis provides a rather convincing verification of the terms of trade theory since the formation of an FTA between a few countries can be reasonably interpreted as an exogenous event from the perspective of the rest of the world.
\end{abstract}

Keywords: Free Trade Agreement, Terms of Trade, Optimal Tariffs.. JEL Classifications: F13, F14.

\footnotetext{
${ }^{*}$ Department of Economics, Vanderbilt University, Nashville, TN 37235-1828. Phone: 615-322-3237; e-mail: kamal.saggi@vanderbilt.edu.

${ }^{\dagger}$ Faculty of Liberal Arts and Professional Studies, York University, Toronto, Canada. Phone: 4167362100 x22833; e-mail: andreyst@yorku.ca.

${ }^{\ddagger}$ Department of Economics, Ryerson University, 350 Victoria Street, Toronto, ON, Canada M5B 2K3. Phone: 416-979-5000 (ext 6689); e-mail: hyildiz@ryerson.ca.
} 


\section{Introduction}

Preferential trade agreements (PTAs) are a feature of the global trade policy landscape like never before. Much attention has been devoted to how such trade agreements might affect tariff policies of member countries towards not only each other but also non-members. However, to the best of our knowledge, we know little about whether and how the formation of PTAs affects the trade policies of non-member countries. In fact, in both theoretical and empirical analyses of PTAs, it is customary to either completely ignore the trade policies of non-members or assume that they are unaffected by PTA formation. For reasons we explain below, this is an important omission from a conceptual as well as a practical perspective. In this paper, we investigate both theoretically and empirically the effects of free trade agreements (FTAs) - the most commonly occurring type of PTA - on the tariffs of non-member countries. Our empirical work is motivated by a simple theoretical framework based on Horn, Maggi, and Staiger (2010).

Existing literature has shown that the formation of an FTA can induce member countries to lower their tariffs on non-members: this is the so called tariff complementarity effect (Bagwell and Staiger, 1997). The intuition underlying this surprising effect is quite robust and clean. As Maggi (2014) notes, if two countries possessing market power sign an FTA, they start to import more from each other and less from non-members and this trade diversion reduces their incentives to manipulate their terms of trade vis-a-vis non-members, which ultimately results in lower external tariffs on their part. Empirical support for the tariff complementarity result has been provided by Estevadeordal, Freund, and Ornelas (2008), Calvo-Pardo, Freund, and Ornelas (2009), and Bohara, Gawande, and Sanguinetti (2004).

The key insight underlying our paper is that the logic underlying the tariff complementarity effect also ought to apply to the optimal tariffs of non-member countries provided they possess the ability to influence their terms of trade. In a world with increasing production costs, if two countries undertake bilateral trade liberalization via an FTA their mutual trade increases while their exports to other countries fall. This change in the pattern of international trade reduces the ability and the incentive of non-member countries to manipulate their terms of trade viz-aviz FTA members, a mechanism that ought to induce non-members to voluntarily lower their tariffs on FTA members. To the best of our knowledge, this insight regarding the effect of FTAs on tariffs of non-member countries has been generally overlooked in the literature.

In this paper, we first formally develop this insight in a simple economic framework based on Horn, Maggi, and Staiger (2010) and then provide empirical evidence in its support. The 
theoretical framework is a classical partial equilibrium set-up comprising an arbitrary number $(n)$ of countries who produce a single numeraire good $v_{0}$ and $n$ non-numeraire goods, where the marginal cost of production of each non-numeraire good increases with output. The pattern of comparative advantage is such that each country exports a unique good to all its trading partners, i.e., the underlying trade pattern is one of competing importers. An important feature of this economic framework is that if two countries liberalize trade towards one another, they import more from each other but simultaneously start exporting less of their comparative advantage good to the rest of the world - a phenomenon we call external trade diversion.

We first derive optimal tariffs in the absence of any trade agreement and then consider how the formation of an FTA amongst $m$ countries, $m<n$, affects the tariffs of a typical non-member country. We show that the export supply elasticities facing non-member countries increase with the size of the FTA (as measured by the number of FTA partners $m$ ) as well as the external tariff preference margin enjoyed by a typical FTA member. Thus, FTAs reduce export supply elasticities facing non-member countries, inducing them to lower their tariffs.

However, bringing this prediction directly to the data is problematic because we do not observe variation in export supply elasticities across countries and industries over time. Our empirical framework is based on another related prediction of the model which links unobservable changes in export supply elasticities to observable changes in trade flows between FTA member countries. Specifically, the model predicts that the increase in the export supply elasticities of non-members is larger and the reduction in their external tariffs is deeper when the effect of an FTA on preferential trade between member countries is larger. To operationalize this prediction, for every country in our sample we construct a measure of a trade-weighted average change in preferential trade flows of its main trade partners. This measure, which we call preferential export share, has a strong theoretical relationship to export supply elasticities and the data reveals that it indeed reflects the variation in elasticities over time. In particular, when we split our sample of countries into two halves by time we find that an increase in the preferential export share of a country's average partner between the two periods is associated with an increase in its export supply elasticity, estimated using the Broda and Weinstein (2006) methodology.

Building on the insights of the model, we set out to empirically investigate whether countries indeed adjust trade policies in response to FTA formation by other countries. Our main empirical focus is on the relationship between changes in MFN tariff rates of countries and preferential export shares. To construct a measure of the annual change in the preferential 
export share of a country's average trade partner, we use industry-level bilateral trade data for 192 importing and 253 exporting countries, along with the information on all FTAs formed between 1989 and 2011.

Our estimation results support the external trade diversion hypothesis. We find that the formation of an FTA by a group of countries and the associated increase in the share of trade between them induces other countries to lower their MFN tariffs. The results are both statistically significant and economically sizable. For example, in our benchmark specification, if a country's preferential exports increase by $10 \%$ as a result of a new FTA, and its share in imports of another non-member country is $10 \%$, the latter reduces its MFN tariff by 0.08 percentage points. This result is remarkably robust to the inclusion of a broad set of fixed effects, including country-year and country-industry fixed effects. Moreover, the effect is the most pronounced for trade-creating FTAs which increase the share of preferential trade between members and, according to the theory, result in greater increase in the export supply elasticities for non-members.

We pay close attention to endogeneity issues and use several instrumental variables strategies to determine whether the effect of FTAs on tariffs of non-member countries is causal. The first endogeneity concern arises from the simultaneity between MFN tariffs and import shares. We address this problem by instrumenting for a country's export pattern using a geography-based gravity model in the spirit of Frankel and Romer (1999). The second source of endogeneity is the presence of omitted variables which could affect trade flows between FTA member countries for reasons unrelated to agreement formation. In order to better isolate variation in preferential trade shares which is due to the effect of preferential trade agreements, we instrument preferential export shares with pre-determined geographic variables using the insights of Baier and Bergstrand (2004). Overall, our IV estimates point to an even stronger external trade diversion effect of FTAs. Moreover, the dynamics of the effect are also consistent with our expectations. In particular, we find external trade diversion to be the strongest in the second and the third years of FTA implementation - the period of the most intense trade liberalization for most agreements - but not in the subsequent years when the effects of preferential liberalization on trade have basically been exhausted. Also, the effect of FTAs on tariffs of non-members is insignificant in the first year, suggesting that countries do not immediately adjust their trade policies to term-of-trade shocks.

The policy implications of our results are clear as well as important. If the formation of FTAs can cause trade liberalization to spillover to excluded countries, an important welfare gain 
accruing from their formation has been ignored thus far in not just the academic literature but also in policy analysis. The literature addressing whether FTAs are building or stumbling blocs for further liberalization in the world economy has tended to focus primarily on the effects FTAs have on the incentives for further liberalization of members - see, for example, Krishna (1998) and Bagwell and Staiger (1997). Our analysis shows that the scope of this line of inquiry needs to be broadened to also include the effects that FTAs might have on the policies of non-member countries.

Terms of trade effects plays a central role in our analysis, and the results of our study complement the empirical research investigating the role terms of trade motives play in determining trade policy. Broda, Limão, and Weinstein (2008) confirm that non-WTO countries indeed manipulate their terms of trade by setting higher tariffs on goods that are supplied inelastically. Several recent studies identify the terms of trade effect from trade policy re-negotiations imposed by multilateral agreements. Bagwell and Staiger (2011) focus on changes in tariff rates resulting from a country's accession to the WTO and Ludema and Mayda (2013) examine variation in MFN tariffs resulting from the Uruguay Round of trade negotiations. In line with the predictions of the terms of trade theory, both studies find that countries reduce tariffs to a deeper degree in industries in which they have greater market power. Using data on import tariffs imposed by the United States on 49 countries during 1997-2006 under its anti-dumping and safeguard laws duties, Bown and Crowley (2013) provide an empirical confirmation of the managed trade theory of Bagwell and Staiger (1990) in which countries play a repeated game and any trade agreement between them has to be self-enforcing. Our paper contributes to this literature by identifying FTAs as a source of exogenous shocks to the terms of trade of all non-members countries. We demonstrate that non-member countries reduce their MFN tariffs in response to negative terms of trade shocks associated with FTAs. In a sense, our analysis

provides perhaps one of the cleanest tests of the terms of trade theory since the formation of an FTA between a few countries can be reasonably interpreted as an exogenous event from the perspective of the rest of the world. Thus, our empirical results provide a rather novel confirmation of the terms of trade theory.

\section{Theoretical model}

Our motivating economic framework is a suitably adapted version of the two-country model of Horn, Maggi, and Staiger (2010). We consider a perfectly competitive world comprising $n$ 
large countries that produce $n$ (non-numeraire) goods and a single numeraire good $v_{0}$. We first describe the underlying economic structure and then derive optimal tariffs in the absence as well as the presence of a free trade agreement (FTA) comprising of an arbitrary number of countries.

On the demand side, the representative citizen's utility function is given by:

$$
U\left(\mathbf{v}, v_{0}\right)=u(\mathbf{v})+v_{0}
$$

where $\mathbf{v}$ is the consumption vector for the $n$ non-numeraire goods, $v_{0}$ denotes the consumption of the numeraire good. We assume $u(\mathbf{v})$ is quadratic and additively separable in the three non-numeraire goods so that demand for good $g$ in country $z$ is given by

$$
d_{z}^{g}\left(p_{z}^{g}\right)=\alpha-p_{z}^{g}
$$

where $p_{z}^{g}$ denotes the consumer price of good $g$ in country $z .{ }^{1}$ Assuming that the population in each country is a continuum of measure one, we can write the consumer surplus associated with good $g$ in country $z$ as:

$$
C S_{z}^{g}\left(p_{z}^{g}\right)=u_{z}^{g}\left[d_{z}^{g}\left(p_{z}^{g}\right)\right]-p_{z}^{g} d_{z}^{g}\left(p_{z}^{g}\right)
$$

On the supply side, as in Horn, Maggi, and Staiger (2010), the production of one unit of the numeraire requires one unit of labour $(l)$. The supply of labor is assumed to be large enough that the numeraire good is always produced in a positive amount and the equilibrium wage is equal to one.

The production technology for non-numeraire goods is subject to diminishing returns. In particular, the production function for (non-numeraire) good $g$ in country $z$ is $Q_{z}^{g}=\sqrt{2 \lambda_{z}^{g} l_{g}}$, where $Q_{z}^{g}$ is the output of good $g$ in country $z$ and $l_{g}$ is the labor employed in good $g$. The corresponding supply function of good $g$ in country $z$ is as follows:

$$
s_{z}^{g}\left(q_{z}^{g}\right)=\lambda_{z}^{g} q_{z}^{g}
$$

where $q_{z}^{g}$ denotes the producer price for good $g$ in country $z$.

The structure of comparative advantage is assumed to be symmetric across countries: $\lambda_{z}^{g}=$ $1+\lambda$ for $g=g_{z}$ while $\lambda_{z}^{g}=1$ for $g \neq g_{z}$. In other words, each country has a comparative advantage in a single good (i.e. country $z$ has comparative advantage in good $g_{z}$ ) while having

\footnotetext{
${ }^{1}$ In Appendix B we extend the model to the one with general demand and supply functions.
} 
a comparative disadvantage in the remaining $n-1$ goods. Thus, there are $n-1$ competing importers for each non-numeraire good. Country z's producer surplus in good $g$ is easily calculated:

$$
P S_{z}^{g}\left(q_{z}^{g}\right)=\int s_{z}^{g}\left(q_{z}^{g}\right) d q_{z}^{g}=\frac{1}{2} \lambda_{z}^{g}\left(q_{z}^{g}\right)^{2}
$$

As a representative scenario for all goods and countries, consider good $g_{z}$ (i.e. the good in which country $z$ has a comparative advantage). Let $t_{z}^{g}$ be the MFN tariff imposed by country $z$ on its imports of good $g .{ }^{2}$ Given that all countries are large, world price of good $g$ depends on the tariffs of all importing countries but to simplify notation we suppress the dependence of prices on tariffs and simply denote the price of good $g$ in country $z$ by $p_{z}^{g}$.

Since country $z$ imposes no tariff on good $g_{z}$, the consumer and producer prices of good $g_{z}$ in country $z$ are equal: $q_{z}^{g_{z}}=p_{z}^{g_{z}}$. Similarly, as there is no domestic taxation of the import competing sectors, producer and consumer prices are also equal: $q_{z}^{g}=p_{z}^{g}$, where $g \neq g_{z}$. Ruling out prohibitive tariffs yields the following no-arbitrage conditions for good $g_{z}$ in importing country $c$ :

$$
p_{c}^{g_{z}}=p_{z}^{g_{z}}+t_{c}^{g_{z}}, c \neq z
$$

Let $m_{c}^{g_{z}}$ be the imports of good $g_{z}$ by country $c$ :

$$
m_{c}^{g_{z}}=d\left(p_{c}^{g_{z}}\right)-s_{c}^{g_{z}}\left(p_{c}^{g_{z}}\right), c \neq z
$$

Similarly, let $x_{z}^{g_{z}}$ denote country $z$ 's exports of good $g_{z}$ to country $c$ :

$$
x_{z c}^{g_{z}}=s_{z}^{g_{z}}\left(p_{z}^{g_{z}}\right)-\sum_{c^{\sim} \neq z, c} d\left(p_{c^{\prime}}^{g_{z}}\right)
$$

Market clearing for good $g_{z}$ requires that country $z$ 's export to country $c$ equals the imports of that country:

$$
x_{z c}^{g_{z}}=m_{c}^{g_{z}}
$$

Country c's welfare is defined as the sum of consumer surplus, producer surplus, and tariff revenue over all goods:

$$
w_{c}=\sum_{g} C S_{c}^{g}\left(p_{c}^{g}\right)+\sum_{g} P S_{c}^{g}\left(p_{c}^{g}\right)+\sum_{g \neq g_{c}} t_{c}^{g} m_{c}^{g}
$$

In the absence of any trade agreement, each country chooses its tariffs to maximize its welfare. To derive optimal tariffs, we follow the approach of Feenstra (2004) and Broda, Limão,

\footnotetext{
${ }^{2}$ We assume that tariff revenues for each good are redistributed unifomly to all individuals.
} 
and Weinstein (2008). Consider country c's tariff problem for good $g_{z}$. Differentiating $w_{c}$ with respect to $t_{c}^{g_{z}}$, we obtain:

$$
\frac{\partial w_{c}}{\partial t_{c}^{g_{z}}}=t_{c}^{g_{z}} \frac{\partial m_{c}^{g_{z}}}{\partial p_{c}^{g_{z}}} \frac{\partial p_{c}^{g_{z}}}{\partial t_{c}^{g_{z}}}-m_{c}^{g_{z}} \frac{\partial p_{z}^{g_{z}}}{\partial t_{c}^{g_{z}}}
$$

The first term of the above first order condition captures the efficiency cost of the tariff (i.e. the marginal deadweight loss of the tariff) while the second term captures the terms of trade effect, that is, the reduction in the world price of good $g_{z}$ that accrues to country $z$ multiplied by the quantity of country c's imports from country $z$.

The optimal tariff is computed where (11) equals zero:

$$
\frac{\partial w_{c}}{\partial t_{c}^{g_{z}}}=0 \Rightarrow \frac{t_{c}^{g_{z}}}{p_{z}^{g_{z}}}=\frac{\frac{\partial p_{z}^{g_{z}}}{\partial t_{c}^{g_{z}}} \frac{m_{c}^{g_{z}}}{p_{z}^{g_{z}}}}{\frac{\partial m_{c}^{g z}}{\partial p_{c}^{g z}} \frac{\partial p_{c}^{g_{z}}}{\partial t_{c}^{g_{z}}}}
$$

Since $m_{c}^{g_{z}}=x_{z c}^{g_{z}}$, we must have

$$
\frac{\partial m_{c}^{g_{z}}}{\partial p_{c}^{g_{z}}} \frac{\partial p_{c}^{g_{z}}}{\partial t_{c}^{g_{z}}}=\frac{\partial x_{z c}^{g_{z}}}{\partial t_{c}^{g_{z}}}
$$

Substituting this into (12) shows that country c's optimal ad-valorem tariff on good $g_{z}$ equals the inverse of the elasticity of the export supply curve faced by country $c$ for that good, denoted by $\varepsilon_{c}^{g_{z}}$ :

$$
\frac{t_{c}^{g_{z}}}{p_{z}^{g_{z}}}=\frac{1}{\varepsilon_{c}^{g_{z}}}=\left[\frac{\partial x_{z c}^{g_{z}}}{\partial p_{z}^{g_{z}}} \frac{p_{z}^{g_{z}}}{x_{z c}^{g_{z}}}\right]^{-1}
$$

Using the demand and supply functions in equations (2) and (4) as well as the no arbitrage and market clearing conditions in (6) and (9), we can obtain the equilibrium price, as well as export and import volumes of good $g_{z}$.

To derive the implications of the formation of an FTA on MFN tariffs of excluded countries, suppose country $z$ forms an FTA with $m$ countries and country $c$ is a non-member. ${ }^{3}$ Let $\widehat{t^{g z}}$ denote the preferential internal tariff on good $g_{z}$ within the FTA imposed by country $z$ 's FTA partners and let $t_{\sim c}^{g_{z}}$ denote the tariff of a typical non-member country other than country $c .{ }^{4}$

It is easy to show that country $z$ 's export supply function of good $g$ to country $c$ is as follows:

$$
x_{z c}^{g_{z}}=[2(n-1)+\lambda] p_{z}^{g_{z}}-(n-1) \alpha+2(n-1) t_{c}^{g_{z}}-2 m\left(t_{\sim c}^{g_{z}}-\widehat{t^{g_{z}}}\right)
$$

Before proceeding with the derivation of optimal tariffs in the presence of an FTA, it is useful to highlight an important feature of our economic framework. If two countries liberalize trade

\footnotetext{
${ }^{3}$ When $m=0$, we are back to the status quo of optimal tariffs in the absence of an FTA.

${ }^{4}$ Here, for the sake of clarity, we report country c's optimal tariff as a function of exogenously given internal and external tariffs of other countries. We report the export supply elasticity and optimal tariff expressions in the Appendix A.
} 
towards one another, they import more from each other and start exporting less to the other countries owing to the fact that the marginal cost of production is increasing - a phenomenon we call external trade diversion. As we will see below, this reduction in the volume of exports of members to excluded countries has implications for their optimal tariffs.

It is immediate from (14) that the formation of an FTA affects country z's export supply function through two key channels: the size of the FTA (as measured by the number of FTA partners $m$ ) and the external tariff preference margin $\varphi_{e x t}^{g_{z}}$ enjoyed by members within an FTA relative to tariffs they face in non-member countries, where $\varphi_{\text {ext }}^{g_{z}} \equiv t_{\sim_{c}}^{g_{z}}-\widehat{t^{g_{z}}}$. These two channels represent the extensive and intensive margins of preferential trade liberalization respectively. Along the extensive margin, the export supply of country $z$ to country $c$ decreases with the size of FTA : $\frac{\partial x_{z c}^{g}}{\partial m}<0$. Similarly, along the intensive margin, the export supply of country $z$ to country $c$ also decreases in the FTA's external tariff preference margin $\varphi_{e x t}^{g_{z}}: \frac{\partial x_{z c}^{g z}}{\partial \varphi_{e x t}^{g z}}<0$.

Given the export supply function above, the export supply elasticity $\varepsilon_{c}^{g_{z}}$ faced by nonmember country $c$ can be calculated as follows:

$$
\varepsilon_{c}^{g_{z}}=\frac{[2(n-1)+\lambda]\left[n \alpha+2 m \varphi_{e x t}^{g_{z}}-2(n-2) t_{\sim_{c}}^{g_{z}}-2 t_{c}^{g_{z}}\right]}{\alpha \lambda-[4(n-1)+2 \lambda] t_{c}^{g_{z}}-4 m \varphi_{\text {ext }}^{g_{z}}+4(n-2) t_{{ }_{c}}^{g_{z}}}
$$

Note that the export supply elasticity $\varepsilon_{c}^{g_{z}}$ increases in both $m$ and $\varphi_{\text {ext }}^{g_{z}}$ :

$$
\frac{\partial \varepsilon_{c}^{g_{z}}}{\partial m}>0 \text { and } \frac{\partial \varepsilon_{c}^{g_{z}}}{\partial \varphi_{\text {ext }}^{g_{z}}}>0
$$

It also proves useful to consider how the two main attributes of an FTA (i.e. $m$ and $\varphi_{\text {ext }}^{g_{z}}$ ) affect its overall trade pattern. Suppose country $z$ negotiates an FTA with $m$ countries. The share of country $z$ 's exports of good $g_{z}$ flowing to its $m$ FTA partners equals:

$$
P X S_{z g_{z}}=\frac{\sum_{j \in m} x_{z j}^{g_{z}}}{\sum_{j \neq z} x_{z j}^{g_{z}}}
$$

We refer to $P X S_{z g_{z}}$ as country z's preferential export share.

In the absence of any FTA (which we denote as regime $\phi$ ), due to symmetry, the share of country z's exports of good $g_{z}$ flowing to any $m$ countries is $P X S_{z g_{z}}(\phi)=\frac{m}{n-1}$. In other words, when country $z$ is not a participant in any FTA, the share of its exports going to any $m$ countries equals $P X S_{z g_{z}}(\phi)$.

Following the formation of the FTA, it is straightforward to show that preferential export 
share of country $z$ in good $g_{z}$ becomes:

$$
P X S_{z g_{z}}=\frac{m\left[\lambda\left(\alpha-2 \widehat{t^{g_{z}}}\right)+4\left[(n-m) \varphi_{e x t}^{g_{z}}-t_{\tau_{c}}^{g_{z}}\right]\right]}{\alpha \lambda(n-1)+2(\lambda+2)\left[m \varphi_{\text {ext }}^{g_{z}}-(n-1) t_{{ }_{c}}^{g_{z}}\right]}
$$

where direct calculations show that

$$
\frac{\partial P X S_{z g_{z}}}{\partial m}>0 \text { and } \frac{\partial P X S_{z g_{z}}}{\partial \varphi_{\text {ext }}^{g_{z}}}>0
$$

Therefore, both the preferential export share of a typical FTA member country $z$ and the export supply elasticities facing non-member countries increase with the size of the FTA $(m)$ as well as the FTA's tariff preference margin $\left(\varphi_{\text {ext }}^{g_{z}}\right)$.

From here on, we utilize parameters $m$ and $\varphi_{\text {ext }}^{g_{z}}$ to capture changes in both the preferential export share and the export supply elasticity. The change in the preferential export share of country $z$ due to the formation of an FTA equals:

$\Delta P X S_{z g_{z}}=P X S_{z g_{z}}-P X S_{z g_{z}}(\phi)=\frac{2 m(n-m-1)(\lambda+2 n) \varphi_{\text {ext }}^{g_{z}}}{(n-1)\left[\alpha \lambda(n-1)+2 m(\lambda+2) \varphi_{\text {ext }}^{g_{z}}-2(\lambda+2)(n-1) t_{\sim c}^{g_{z}}\right]}>0$

Note that for any given FTA of size $m$, the greater the external tariff preference margin, the larger the increase in the preferential export share: $\frac{\partial \Delta P X S_{z g_{z}}}{\partial \varphi_{e x t}^{g z}}>0 .{ }^{5} \mathrm{~A}$ similar analysis holds for country c's optimal tariff.

Using (13) and (15), non-member country c's optimal tariff when country $z$ forms an FTA with $m$ other countries is equal to:

$$
t_{c}^{g_{z}}=\frac{2 \alpha \lambda+8\left[(n-2) t_{\sim_{c}}^{g_{z}}-m \varphi_{e x t}^{g_{z}}\right]}{[2(n-1)+\lambda][4(n+1)+2 \lambda]}
$$

It is immediate from above that the tariffs imposed by different non-member countries on the same good are strategic complements in our model:

$$
\frac{\partial t_{c}^{g_{z}}}{\partial t_{\tau_{c}}^{g_{z}}}>0
$$

The intuition for why tariffs of different countries end up being strategic complements is that an increase in the tariff $t_{\tau_{c}}^{g z}$ increases the volume of country $z$ 's exports to country $c$ thereby increasing the latter's ability to manipulate its terms of trade.

\footnotetext{
${ }^{5}$ Note that $P X S_{z g_{z}}$ rises with $m$ at an increasing rate when $m$ is sufficiently small. As $m$ goes to $n-1$, we approach global free trade in good $g_{z}$ and thus $P X S_{z g_{z}}$ converges to $P X S_{z g_{z}}(\phi)=\frac{m}{n-1}$.
} 
Note that as the preferential export share rises either due to an increase in the size of the FTA $(m)$ or due to its preference margin $\left(\varphi_{e x t}^{g_{z}}\right)$, the external trade diversion caused by the FTA induces the non-member country to lower its tariffs on members:

$$
\frac{\partial t_{c}^{g_{z}}}{\partial m}<0 \text { and } \frac{\partial t_{c}^{g_{z}}}{\partial \varphi_{e x t}^{g_{z}}}<0
$$

The optimal pre-FTA MFN tariff of country $c$ can be found by setting $\varphi_{e x t}^{g_{z}}=0$ in (21), which yields:

$$
t_{c}^{g_{z}}(\phi)=\frac{2 \alpha \lambda+8\left[(n-2) t_{-c}^{g_{z}}\right]}{[2(n-1)+\lambda][4(n+1)+2 \lambda]}
$$

Using (21) and (24), we can directly calculate the change in the optimal MFN tariff of nonmember country $c$ as a function of $m$ and $\varphi_{e x t}^{g_{z}}$ :

$$
\Delta t_{c}^{g_{z}}=t_{c}^{g_{z}}(\phi)-t_{c}^{g_{z}}=\frac{m \varphi_{e x t}^{g_{z}}}{[2(n-1)+\lambda][4(n+1)+2 \lambda]}
$$

where $\frac{\partial \Delta t_{c}^{g_{z}}}{\partial m}>0$ and $\frac{\partial \Delta g_{\varphi_{z z}}^{g_{z}}}{\partial \varphi_{e x t}}>0$. The following proposition summarize our central theoretical finding:

Proposition 1: The larger the increase in preferential export share of FTA member countries, the greater the reduction in the external tariffs of non-member countries.

The intuition for this proposition is clear: the greater the degree of external trade diversion caused by an FTA, the lower incentives of non-members to manipulate their terms of trade via import tariffs. Proposition 2 in the Appendix B shows that the same result holds under a general demand and supply structure as long as the inverse supply function is log-concave.

\section{Empirical model and data}

\subsection{Empirical model}

The theoretical model illustrates the relationship between FTA formation and the change in import tariffs of excluded countries. In general, the optimal import tariff of country $c$ for industry $i$ in year $t$ is equal to the inverse of the export supply elasticity: ${ }^{6}$

$$
\tau_{c i t}=1 / \varepsilon_{c i t}
$$

\footnotetext{
${ }^{6}$ For notational clarification, since the empirical results are based on industry level data, we use $i$ to denote industries.
} 
When a group of countries form an FTA, it re-directs their trade flows towards member countries, reducing their export supply to the rest of the world. The resulting increase in $\varepsilon_{c i t}$ faced by all non-member countries will stimulate a reduction in their import tariffs. Thus, the empirical model should relate changes in import tariffs to changes in the export supply elasticities caused by trade agreements of other countries. However, a direct test of this relationship requires information on product-specific changes in export supply elasticities of a country attributable to formation of trade agreements between its partners, which is unobservable: the existing empirical methods for estimating export supply elasticities at the product level rely on time variation to identify structural parameters and do not allow estimating changes in $\varepsilon_{\text {cit }}$ over time. ${ }^{7}$

To deal with this problem, our main empirical test is based on Proposition 1 which builds a theoretical relationship from unobservable changes in elasticities to observable changes in trade shares. Intuitively, a greater increase in trade between FTA member countries implies stronger external trade diversion and larger increase in $\varepsilon_{c i t}$, reducing welfare-maximizing tariffs by all non-member countries. Using this insight, the simplest structure to study the relationship between FTA formation and MFN tariffs of excluded countries is

$$
\Delta M F N_{c i t}=\beta \Delta P X S_{c i t-1}+v_{c i t}
$$

where $\triangle M F N_{c i t}$ is the annual change in the MFN tariff rate of country $c$ for industry $i$ in time $t$ and $\triangle P X S_{c i t}$ is the annual change in the preferential export share of country c's average trade partner. The main explanatory variable is lagged by one period in order to minimize any possible simultaneity problem. Given that each country has multiple trading partners, we construct $P X S_{c i t}$ as a weighted average of preferential exports of country c's partners using their import shares as weights:

$$
\begin{gathered}
\Delta P X S_{c i t}=\left(\sum_{p \neq c} i m p \_s h a r e_{c p i} \cdot \Delta P R E F \_S H A R E_{p i t}\right) \\
\Delta P R E F_{-} S H A R E_{p i t}=\sum_{j \neq i} F T A_{p j t} \cdot \Delta e x p \_ \text {share }_{p j i t}
\end{gathered}
$$

where $i m p \_s h a r e_{c p i}$ is the sample-average share of country $p$ in total imports of industry $i$ by country $c$, exp_share $e_{j i t}$ is the share of country $p$ 's exports of good $i$ to country $j, F T A_{p j t}$ is a binary variable which takes the value of one if countries $p$ and $j$ have an FTA in year $t$ and zero otherwise, and PREF_SHARE $E_{\text {pit }}$ is the share of country p's exports of good $i$ to its FTA

\footnotetext{
${ }^{7}$ See Hillberry and Hummels (2013) for the overview of the literature on the estimation of import demand and export supply elasticities.
} 
partner countries excluding $c$. Note that import shares, used as weights in equation (26), are constructed as averages over the entire sample period for each country-pair and industry. This is done in order to reduce the measurement error and to bring the empirical specification closer to the theory, which predicts that the effect of trade agreements operates through changes in preferential export share of a country's trade partners. Therefore, the variation in $P X S$ measure over time for each country-industry pair is driven only by the variation in preferential export share of a country's trade partners rather than by the variation in its own trade structure.

In equation (25), $\beta<0$ would support the external trade diversion hypothesis, where countries lower their tariffs in response to an increase in the share of preferential exports of their trade partners. However, equation (25) only captures the correlation between the change in the MFN tariff and the lagged change in preferential export share by an average partner country, while it may take more than one year for trade policy to respond to changes in market conditions. To capture the dynamics of the response of MFN tariffs to FTA formation by other countries, we analyze the differential effect of the change in preferential export shares by trade partners within the first five years of FTA formation:

$$
\begin{aligned}
& \Delta M F N_{c i t}=\sum_{T=1}^{5} \beta_{T} \Delta P X S(T)_{c i t-1}+v_{c i t} \\
& \Delta P X S(T)_{c i t-1}=\left(\sum_{p} i m p_{-} \operatorname{share~}_{c p i} \cdot \Delta P R E F \_S H A R E(T)_{p i t-1}\right) \\
& \Delta \text { PREF_SHARE }(T)_{p i t-1}=\sum_{j \neq c} F T A(T)_{p j t} \cdot \Delta_{T} \text { exp_share }{ }_{p j i t-1}
\end{aligned}
$$

where $F T A(T)_{p j t}$ is a binary variable which takes the value of one if an FTA between countries $p$ and $j$ was established in year $(t-T)$ and $\Delta_{T} x_{t}=\left(x_{t}-x_{t-T}\right)$. Thus, for all countries which formed FTAs with country $p$ in year $(t-T), \triangle P R E F \_S H A R E(T)_{p i t-1}$ will measure the change in the share of those countries in total exports of industry $i$ by country $p$ between years $(t-1)$ and $(t-T-1)$. The effect of agreements formed more than five years ago is combined into one general category $P X S(T=6)_{c i t-1}$.

Specification (27) is still too parsimonious, however, and disregards other determinants of a country's trade policy which may be related to its own or its partners' trade structure. Our three-dimensional panel enables us to use a variety of fixed effects to control for a wide array 
of omitted variables. Incorporating those fixed effects in model (27) we obtain:

$$
\Delta M F N_{c i t}=\sum_{T=1}^{6} \beta_{T} \Delta P X S(T)_{c i t-1}+\gamma_{c t}+\gamma_{c i}+v_{c i t}
$$

The country $\times$ year fixed effect $\gamma_{c t}$ will absorb not only inherent country characteristics that do not vary over the sample period, such as geographic, political and institutional factors, but also the effect of time-varying country characteristics on trade policy changes. This includes general episodes of country-specific trade liberalization, accession to the WTO and regional trade agreements, changes in fiscal and monetary policies, variation in exchange rates and balance of payments, and other macroeconomic characteristics that affect general changes in tariff policies in specific countries and periods. Country $\times$ industry fixed effects $\gamma_{c i}$ will control for economic and political factors that may affect the average changes in the level of protection in different industries within a country. In particular, $\gamma_{c i}$ will capture a government's potential reluctance to liberalize trade in certain sensitive industries and the possibility for more rapid tariff reductions in other industries.

A concern remains that some factors with the country $\times$ industry $\times$ time variation may be correlated with both MFN tariffs and the preferential trade structure of a country's trade partners. One of those factors, identified in the previous literature, is reciprocity in trade negotiations. Reciprocity is an important principle of the WTO and since our sample period covers the Uruguay round of tariff cuts it may play an important role in our empirical analysis. In the presence of reciprocal tariff negotiations, a reduction in the MFN tariff by a country will affect both the MFN tariffs of its trade partners and the share of its preferential exports in the following period, causing a simultaneity problem in equation (29). Following Limão (2006), we address it by introducing the market access control variable:

$$
\Delta m a_{c i t}=\sum_{p} i m p \_\operatorname{share~}_{c p i}\left(\sum_{n} i m p \_\operatorname{share~}_{p n} \cdot \Delta M F N_{p n t}\right)
$$

The expression in brackets is the weighted average change in the MFN tariffs of country $p$ across all product lines $n$, which is then averaged across all exporters $p$ of product $i$ to country c. Since the GATT principle supplier rule states that countries negotiate only with their top exporters, the latter aggregation is performed only over the top five main suppliers of product $i$ to country $c$. 


\subsection{Addressing endogeneity issues}

Key to our identification strategy is that the decision to form an FTA is independent of future changes in trade policies by other countries. ${ }^{8}$ However, import shares and preferential export shares, used in the construction of our main explanatory variables, may not be fully exogenous. Although the broad set of fixed effects allows to control for many possible unobservables and remove most of the omitted variables, this does not resolve all potential endogeneity issues with various components of the explanatory variables. In this section we first discuss identification problems associated with import shares, and then focus on endogeneity of preferential export shares.

A potential threat with using import shares as weights in the construction of $P X S(T)$ variables is that imports may be simultaneously determined with import tariffs. This concern would be even more serious if reductions in import tariffs have differential impact on imports from partners with different preferences for regional trade liberalization. For example, if countries that are more actively involved in preferential trade benefit more from trade liberalization by others, than a reduction in import tariffs will increase the share of imports from those countries, thus raising the value of our explanatory variables and causing simultaneity bias in $\beta_{T}$. Although averaging import shares over time will reduce the simultaneity problem, it will not resolve it completely. Another concern with using import shares is that they may partially offset the effect of FTA on preferential export shares. If an FTA between a pair of countries redirects their exports from third countries to each other's markets, as the theory predicts, an increase in preferential export shares of the FTA member countries will be combined with a decrease in import shares of other countries from that FTA, reducing the value of $P X S(T)$ and causing a bias in the estimates.

We address the endogeneity of import shares with the instrumental variable strategy similar to Do and Levchenko (2007), which extends the methodology of Frankel and Romer (1999) to industry-level data. Frankel and Romer (1999) use the gravity model to predict the observed trade flows between a pair of countries using their pre-determined geographic characteristics such as distance, population and other standard covariates of trade costs used in the gravity models. These are reasonable instruments because on one hand they are powerful determinants of trade flows, as the gravity literature demonstrates, ${ }^{9}$ and on the other it is difficult to think

\footnotetext{
${ }^{8} \mathrm{We}$ believe this is a plausible assumption because trade agreements usually take many years to negotiate. By the time an agreement is implimented, MFN tariffs of third countries would have already responded to economic shocks that could potentially triggered those negotiation.

${ }^{9}$ In this study we use the same list of instruments as in Frankel and Romer (1999): log of distance between
} 
of any reasons for why country's geographic characteristics could affect product-specific tariff changes other than through trade flows. Since we need to instrument import shares at the industry level, we allow the coefficients on the covariates in the gravity model to vary across industries, as in Do and Levchenko (2007). This approach is based on the assumption that trade volumes respond differently to geographic characteristics in different industries, which is supported by the data: $70 \%$ of variation in trade values predicted by the model comes from within country-pair-year cells, close to $59 \%$ observed in the data. Following this methodology, we obtain predicted values of trade flows between every country pair for every industry and use them to calculate the predicted "natural" import shares, $i m \widehat{p \_s h} a r e_{c p i}$. Using these values, we form the following measures

$$
I V 1(T)_{c i t-1}=\left(\sum_{p} \widehat{i m p \_s h a r e} e_{c p i} \cdot \Delta P R E F \_S H A R E(T)_{p i t-1}\right)
$$

These variables isolate variation in import shares stemming from changes in either expected MFN tariff changes or preferential trade shares of partner countries. Therefore, as long as $\varepsilon_{c i t}$ is independent of $\triangle P R E F \_S H A R E(T)_{p i t-1}, I V 1(T)$ represent valid instruments for $\triangle P X S(T)$.

Another identification issue with equation (29) relates to preferential export shares used in the construction of the main explanatory variables. The concern here is that these shares are used as proxies for unobservable changes in export supply elasticities. The theoretical model predicts that FTAs affect both the export supply elasticities and the preferential export shares positively, so that changes in the latter can be used to infer changes in the former. However, a change in the share of a country's exports to its FTA trade partners is an imperfect measure of a change in the export supply elasticity as trade shares may vary for a variety of reasons unrelated to the trade agreement and to the export supply elasticity faced by other countries. Therefore, identification of the effect of trade agreements on trade policies of excluded countries in model (29) rests on two assumptions. First, the variation in preferential export shares must to some extent be driven by changes in the export supply elasticities. Second, the remaining variation in preferential export share must be unrelated to the error term in (29).

In the Appendix $\mathrm{C}$ we provide some evidence in support of the first assumption. Using Feenstra (1994) methodology, we estimate the ROW export supply elasticity for every country countries, log of population, log of land size, landlock and common border indicators, and the interactions of all of the above variables with the common border dummy variable. The F-statistics on these terms in the log of imports regression are highly significant for all industries and the average R-squared is 0.2. 
and industry for two time periods: 1988-2001 and 2002-2011. Consistent with our theory, we find a positive and statistically significant relationship between changes in the export supply elasticities and changes in preferential export shares over these two time periods.

Although the variation in preferential export shares is consistent with the terms of trade variation, large measurement error may lead to attenuation bias in $\beta_{T}$ estimates. Moreover, changes in preferential export shares and MFN tariffs of third countries may be determined by some common shocks. Addressing these endogeneity concerns requires isolating variation in preferential export shares which is due to the effect of a trade agreement on trade flows between member countries. To construct such instruments we use the insights of Baier and Bergstrand (2004) who develop a general equilibrium model of trade to determine which economic characteristics are associated with stronger trade creation forces of regional trade agreements. Baier and Bergstrand found that FTAs lead to more trade between member countries and generate stronger welfare gains if the member countries are: closer to each other, more remote from the rest of the world, larger in size, and similar in size (as measured by population). With these geographic variables we predict the effect of an FTA on trade flows between members and obtain a measure of predicted changes in preferential trade shares which are plausibly independent from other determinants of trade policies of non-member countries. Using fitted values for changes in preferential trade shares obtained from this model, we construct the second set of instruments for changes in trade-weighted preferential export shares:

$$
\begin{aligned}
I V 2(T)_{c i t-1} & =\left(\sum_{p} \mathrm{imp \_ sh} \widehat{a r e}_{c p i} \cdot \Delta \operatorname{PREF} \widehat{\operatorname{SHA} R E}(T)_{p i t-1}\right) \\
\Delta P R E F_{-} \widehat{S H A R E}(T)_{p i t-1} & =\sum_{j \neq c} \operatorname{FTA}(T)_{p j t} \cdot \Delta_{T} \text { exp_share }_{p j i t-1}
\end{aligned}
$$

These instruments are functions of pre-determined geographic characteristics of a country's trade partners and FTA dummy variables and provide consistent estimates under the condition that the decision of a pair of third countries to form an FTA is independent of the error term in (29). As an additional set of instruments, $I V 3(T)$, we also use the (import-weighted) change in preferential export share predicted by differences in capital and skilled labor endowments of the FTA member countries. Appendix D lays out the details of the construction of our instruments.

\subsection{Data}

The bilateral trade data for this project are taken from the World Integrated Trade Solutions (WITS) database, maintained by the World Bank, and cover the time period from 1989 to 2011. 
The data that we use to construct trade share variables is a four-dimensional unbalanced panel of 192 importing countries, 253 exporting countries, 98 2-digit HS industries and 22 years. ${ }^{10}$

The binary variable that measures the presence or absence of an FTA in a given year was constructed for all pairs of countries in our sample using the WTO database on Regional Trade Agreements which includes information on the date of notification and the date when the agreement entered into force. We record FTA as being formed in year $t$ if it came into force between July of $(t-1)$ and June of $t$. Since the membership structure of some FTAs vary over time and the WTO database does not always keep track of those changes, the data on bilateral FTA structure was complemented with information from other sources such as official web sites of these agreements. The resulting database covers all complete FTAs that were formed between 1989 and 2011 and includes 2,513 country pairs trading under an FTA clause in 2011, or $6.6 \%$ of all country-pairs in our sample. Without information on coverage of each FTA, we assume that FTAs apply to trade in all industries between their members. Using equation (28) and the data on bilateral trade flows and FTA membership, we construct six measures for changes in preferential export shares of an average partner for every country, industry, and year. We combine this information on preferential trade of an average partner country with the MFN and preferential tariff data from the WITS.

Table 1 reports the basic descriptive statistics for our key variables. The mean ad-valorem MFN tariff is 11.89 percentage points and is decreasing by 0.21 every year, as compared to 0.07 annual percentage percentage reduction in tariff concessions received. The average country in our sample observes a reduction in preferential export shares of its average partner. This reduction is equal to 0.03 percentage points in the first year of the agreements and goes up to 0.01 percentage points reduction by the fifth year. This pattern reflects regularity, observed in most country-pairs and industries, that the share of trade between FTA member countries averaged across industries does not change much over time despite preferential access to each other's markets.

In order to construct instruments for import and preferential export shares, we merge trade data with geography variables obtained from the Centre d'Etudes Prospectives et d'Informations Internationales (CEPII). This database contains information on bilateral distance between each pair of countries, land size of each country, and information on whether two countries are landlocked and share a border. The data on population are taken from the Penn World Tables.

\footnotetext{
${ }^{10}$ We exclude China from the sample because China's increasing ability to penetrate other markets results in a reduction in trade shares between members of most FTAs. However, keeping China in the sample does not materially affect our results, as we show in the robustness section.
} 


\section{Results}

\subsection{Baseline results}

Table 2 presents OLS estimation results for equation (29). All standard errors are clustered at country-product level to correct for serial correlation in the error term. The first column reports the estimates for the most basic specification and columns (2)-(6) add progressively more fixed effects and controls. Overall, an increase in preferential exports of a product by a country's trade partners is associated with a subsequent reduction in its MFN tariffs. The results in our most preferred specification with country-year and country-industry fixed effects in column (6) suggest that the reductions in MFN tariffs peak in the second year after implementation of an agreement and then fall gradually over the next three years. The coefficients on $\triangle P X S(T)$ are statistically significant in the first three years of FTA formation and remain negative but insignificant in the following two years. It should be noted that this result is robust to the inclusion of various fixed effects and the magnitude of the coefficients is fairly stable across specifications. Even the most stringent specification with country-industry, country-year, and industry-year fixed effects in column (5) yields similar estimates to specification with countryyear effects in column $(2) \cdot{ }^{11}$

The estimates from Table 2 point to a potentially non-negligible economic impact of FTAs on tariffs of non-members. For instance, if a country's preferential exports increase by $10 \%$ as a result of a new FTA, and if its share in imports of another country is $10 \%$, the latter will reduce its MFN tariff by $0.11(=0.033+0.047+0.030)$ percentage points in the first three years of the agreement. However, because most FTAs do not lead to substantial increase in trade shares between member countries, ${ }^{12}$ the link between preferential trade shares of FTA members and MFN tariff reductions by non-members is quantitatively not very strong. In particular, a one standard deviation increase in $\triangle P X S(T=2)$ variable is associated with a reduction in the MFN tariff by only $0.01-0.02$ standard deviations, or by $0.04-0.05$ percentage points. Industries in 75 th percentile of $\triangle P X S(T=2)$ distribution have on average 0.0027 percentage points lower MFN tariff relative to industries in the 25th percentile.

\footnotetext{
${ }^{11}$ To estimate the model with muliple high-dimentional fixed effects in column (5) we demean the data by industry-year; hence the R-sqared in column (5) does not account for variation explained by industry-year fixed effects.

${ }^{12}$ For $90 \%$ of all country-pairs and industries in our sample, an increase in the share of preferential trade in total trade of FTA member countries does not exceed one percentage point in the first two years of the agreement.
} 


\subsection{Results with positive and negative changes in preferential export shares}

Our baseline specification (29) assumes that both positive and negative changes in preferential export shares have equal effects on tariffs of other countries. In other words, $\beta_{T}<0$ in equation (29) implies that if FTA member countries begin to trade less after an agreement is formed, other countries will increase their tariffs in response. This result is hard to rationalize within the framework of our theoretical model, which predicts that preferential trade liberalization always redirects FTA members' trade flows towards each other and the expansion of trade between FTA members stimulates other countries to adjust their trade policies. In practice, however, there are many other factors determining trade flows between member countries, and if some of them outweigh trade agreement's potential to generate new trade, there will be no increase in the export supply elasticities and no effect on tariffs of other countries. In Section 4.3, we address this issue formally by instrumenting changes in preferential shares in order to isolate variation stemming from FTA formation.

In this section we present the results for equation (29) with changes in partner countries' preferential export shares calculated separately for positive and negative changes:

$$
\begin{aligned}
& \Delta P X S(T)_{c g t-1}^{P}=\left[\Sigma_{p} i m p \_ \text {share }_{c p g} \cdot \Delta P R E F_{-} S H A R E(T)_{p g t-1}^{P}\right] \\
& \Delta P X S(T)_{c g t-1}^{N}=\left[\Sigma_{p} i m p_{-} \operatorname{share}_{c p g} \cdot \Delta P R E F_{-} S H A R E(T)_{p g t-1}^{N}\right] \\
& \triangle \text { PREF_SHARE }(T)_{p g t-1}^{P}=\sum_{j \neq i} F T A(T)_{p j t} \cdot I(T)_{p j g t-1} \cdot \Delta e x p \_ \text {share }_{\text {pjgt-1 }} \\
& \Delta P R E F \_S H A R E(T)_{p g t-1}^{N}=\sum_{j \neq i} F T A(T)_{p j t} \cdot\left(1-I(T)_{p j g t-1}\right) \cdot \Delta e x p \_s h a r e_{p j g t-1} \\
& I(T)_{p j g t-1}=\left\{\begin{array}{l}
1 \text { if } \Delta e x p \_s h a r e_{p j g t-1}>0 \\
0 \text { if } \Delta e x p \_s h a r e_{p j g t-1}<0
\end{array}\right.
\end{aligned}
$$

The variable $\triangle P X S(T)^{P}$ is analogous to (28) but is calculated only for those FTA country pairs and industries for which trade agreements resulted in greater preferential shares. If only trade-creating FTAs lead to a long-run increase in the export supply elasticity, as the theory predicts, then we would expect the coefficients on $\triangle P X S(T)^{P}$ to be negative and larger in absolute value that the coefficients on $\triangle P X S(T)^{N}$.

Consistently with our expectations, results in Table 3 show that the relationship between FTA formation and tariff reductions by non-members is stronger in those cases when FTA 
triggered an increase in the share of preferential trade between member countries. While trade agreements that result in lower trade shares between members have no statistically significant effect on tariffs of excluded countries, the effect of trade-creating FTAs is nearly twice as strong as that estimated previously for all agreements pooled together. The estimates in column (3) imply that if $10 \%$ of a country's imports is coming from a partner which experienced a $10 \%$ increase in preferential exports, the imports tariff of the former country will fall by almost 0.18 percentage points in three years following formation of the agreement $(0.095+0.032+0.053)$. The result that only trade-creating FTAs are associated with tariff cuts by non-members is consistent with Proposition 1 which states that the effect of a trade agreement on export supply elasticity is stronger when the increase in the volume of trade between member countries is larger. The finding that not all FTAs lead to trade policy adjustments by outside countries also points to the importance of isolating the effect of FTAs on preferential export shares from other influences.

\subsection{Instrumental variable results}

As discussed in Section 3.2, both import shares and preferential export shares can be endogenous in equation (29). In this section we explore the instrumental variable strategy to estimate (29) which relies on the weaker identification assumption than the OLS, specifically that only the decision to form an FTA is exogenous to future tariff changes by other countries.

We begin our analysis by addressing the endogeneity issue of import shares, which we use as weights in (26) to construct changes in preferential exports for an average trade partner. Recall from Section 3.2 that the two main concerns with import shares are their negative relationship with preferential export shares and the reverse causality from changes in import tariffs. Using instruments $I V 1(T)$, constructed with import shares predicted by the gravity model, would allow us to obtain estimates of $\beta_{T}$ which are based on the variation in import shares arising from geographical determinants of trade flows and are thus free from any policy influences.

The estimates with $I V 1(T)$ instruments are reported in columns (1) and (2) of Table 4. The instruments perform well in the first stage of the estimation procedure. The $t$-statistics from the test of the significance of $I V 1(T)$ in the first stage regression of $P X S(T)$ range from 7.5 for $T=1$ to 22.3 for $T \geq 6$. Since we have multiple endogenous variables, we use AngristPischke statistics to assess the strength of our instruments (Angrist and Pischke, 2009). The results, reported in the bottom of Table 4, indicate that weak instruments is unlikely to be a 
problem. We also report the conventional F-statistics for instrument exclusion and they vary from 6.81 for $T=1$ to 32.79 for $T \geq 6 .{ }^{13}$ The second stage estimates are consistent with the main findings of the previous sections. As shown, all coefficients are negative and three of them are statistically significant, indicating that FTAs lead to tariff reductions by non-members.

Table 4 reveals two important differences between the IV and the OLS results. First, the two estimates predict different dynamics for the impact of an FTA on tariff reductions by nonmembers. In contrast to the OLS estimates, the effect implied by the IV estimates is small and not statistically significant in the first year of the agreement but is strong and significant in the second, third, and, somewhat surprisingly, fifth years. Second, the magnitude of the IV estimates is larger than the OLS estimates, and the implied responsiveness of MFN tariffs to changes in preferential export share of an average trade partner is 2-3 times larger with the IV estimates. These results suggest that import shares are indeed endogenous in equation (29), causing a bias in the OLS estimates.

Columns (3) and (4) of Table 4 report results when we treat preferential export shares as endogenous and instrument $P X S(T)$ variables with $I V 2(T)$, discussed in Section 3.2. These instruments not only address the problem of endogeneity of import shares, but also isolate variation in changes in preferential export shares which can be attributed to the effect of FTAs. The results of Angrist-Pischke test indicate strong correlation between our instruments and endogenous regressors in the first stage. Of the six coefficients on $P X S(T)$ variables, two remain negative and statistically significant. Specifically, the estimated effect of FTAs on tariff reduction by outside countries is the strongest in the second and the third years of an agreement. The magnitude of these coefficients is also considerably larger than that for the estimates obtained from the OLS and GMM with $I V 1(T)$ instruments, which is consistent with the presence of attenuation bias in the OLS and GMM with $I V 1(T)$ estimates. Since changes in preferential export shares is an imperfect measure of changes in export supply elasticities, noisy data may bias the coefficient estimates towards zero, and isolating variation in $P X S(T)$ variables which is related to trade agreements and changes in export supply elasticity may improve identification of the effect of our interest.

Similar results are obtained in columns (5) and (6) when we use additional instruments for preferential export shares, $I V 3(T)$, constructed from the predicted effect of factor endowments

\footnotetext{
${ }^{13}$ We cannot apply Stock-Yogo weak identification test since the critical values for this test are only available when the number of endogenous regressions does not exceed three. Using the conventional "rule of thumb" by Staiger and Stock (1997), all F-statistics are close or above 10, suggesting that weak identification is unlikely to be present.
} 
on change in trade volumes between FTA countries. Each $I V 3(T)$ is positive and individually significant in the first stage regression for the corresponding $P X S(T)$ at least at $10 \%$ confidence level, and the Hansen-J over-identification test passes easily.

\section{$5 \quad$ Robustness tests and extensions}

\subsection{Political economy}

Suppose countries are politically biased and attach an additional weight to the domestic producer surplus relative to the other components of welfare. For simplicity, let all members of a prospective trade agreement have symmetric political preferences, with $\beta_{m}$ denoting their political bias. Let the political bias of non-member country $c$ be denoted by $\beta_{c} \geq 1$.

We begin by considering a scenario where country $z$ negotiates an FTA with $m$ other countries. Before the FTA is formed (i.e. we are in regime $\phi$ ), the optimal MFN tariff of an outside country $c$ on imports from $z$ is denoted by $t_{c}^{g_{z}}(\phi)$. Similarly, $t_{m}^{g_{z}}$ denotes the optimal MFN tariff of prospective FTA members prior to the agreement. Once the FTA is in place, the internal tariff of each member country $m$ and the optimal MFN tariff of a non-member country $c$ are denoted by $\widehat{t^{g z}}$ and $t_{c}^{g_{z}}$, respectively.

It is straightforward to show that the formation of an FTA induces non-member countries to reduce their MFN tariffs:

$$
\Delta t_{c}^{g_{z}}=t_{c}^{g_{z}}(\phi)-t_{c}^{g_{z}}=\frac{2\left[\beta_{c}[2(n-1)-\lambda]+4\right]\left[m \varphi_{i n t}^{g_{z}}\left(\beta_{m}\right)\right]}{[2(n-1)+\lambda]\left[4(n+1)+2 \lambda-2(n-2+\lambda) \beta_{c}\right]}>0
$$

where $\varphi_{\text {int }}^{g_{z}}\left(\beta_{m}\right)=t_{m}^{g_{z}}\left(\beta_{m}\right)-\widehat{t^{g_{z}}}$ is the FTA internal preference margin that refers to a reduction in member countries' tariffs following the formation of an FTA. Comparative statics analysis of expression (33) leads to several important testable findings. First, as before, an increase in the preferential export share (along either the intensive or the extensive margins) induces deeper tariff cuts by non-members: $\frac{\partial \Delta t_{c}^{g z}}{\partial m}>0 ; \frac{\partial \Delta t_{c}^{g z}}{\partial \varphi_{i n t}^{g z}\left(\beta_{m}\right)}>0$. Second, the effect of preferential export share on tariffs of non-member countries is amplified by the presence of political bias: $\frac{\partial^{2} \Delta t_{c}^{g_{z}}}{\partial m \partial \beta_{c}}>0$ and $\frac{\partial^{2} \Delta t_{c}^{g z}}{\partial \varphi_{i n t}^{g_{z}}\left(\beta_{m}\right) \partial \beta_{c}}>0$. Hence, non-members with stronger political motivations should respond to trade agreements with deeper tariff cuts. To understand the intuition, first note that the optimal tariff of a non-member country rises with its political bias under any given regime: $\frac{\partial t_{c}^{g_{z}}}{\partial \beta_{c}}>0$. However, relative to no agreement, when country $z$ forms an FTA with $m$ countries, 
the external trade diversion occurs, reducing the effect of political bias on tariff protection: $\frac{\partial t_{c}^{g z}(m=0)}{\partial \beta_{c}}>\frac{\partial t_{c}^{g z}(m)}{\partial \beta_{c}}>0$. Third, non-member countries reduce their tariffs more in response to an FTA if members have larger political bias: $\frac{\partial^{2} \Delta t_{c}^{g_{z}}}{\partial m \partial \beta_{m}}>0$. If prospective FTA members are more politically motivated, they use more protectionist trade policies so that preferential trade liberalization results in more trade between members. In such a case, an FTA would induce deeper tariff cuts by non-members because of the greater increase in preferential trade share induced by it. Therefore, our empirical framework is robust to the presence of political economy motives of the FTA member countries as $P X S(T)$ variables pick up the effect of the members' political preferences.

In order to test whether countries with stronger political preferences in trade policies reduce their tariffs by more in response to FTA formation by other countries, we need data on political preferences by country. We take these data from Gawande, Krishna, and Olarreaga (2009). The authors estimate the protection for sale model by Grossman and Helpman (1994) for 51 countries and quantify the extent to which governments are concerned about national welfare relative to rents of special interest groups. Using the estimates of the relative weight that governments attach to welfare over private interests, $a$, we run several tests for the hypothesis that political preferences lead to stronger response in trade policies to FTA formation.

First, in column (1) of Table 5 we report the estimates of equation (29) augmented with the interactions of $P X S(T)$ variables with the welfare mindedness of governments, $a$. If more politically biased governments (higher $\beta$, lower $a$ ) reduce tariff by more in response to an increase in $P X S(T)$, we would expect to find positive coefficients on $P X S(T) \times a$ variables. The estimates in column $1(\mathrm{~b})$ show that only one of the interactions has a positive and marginally significant coefficient. Next, we estimate the coefficients on $P X S(T)$ variables separately for countries with high and low values of $a$ using different percentile thresholds on $a$ to assign countries one of the two groups. Results with three percentile thresholds, in increasing order of $a$, are presented in Table 5: the 25th percentile (column 2), the 50th percentile (column 3), and the 75th percentile (column 4). For any given threshold, we include the interactions of $P X S(T)$ with a dummy variable $I_{c}$ which takes the value of one for countries with $a_{c}$ above the threshold. Only when we consider countries with the lowest political bias (column 4), we find that they reduce tariffs by less in response to an FTA in the third and the firth year of the agreement. However, insignificant coefficients on $P X S(T) \times I_{c}$ interactions suggest that trade policies of countries with the highest political biases seem to be equally responsive to FTA formation than other countries (column 2). Similar conclusions are drawn from results in column (5) where we add interactions of $P X S(T)$ with the quartile dummy variables for $a$ : 
countries with high $a$ do not seem to adjust their tariffs any different from countries with low $a$. Therefore, there is little evidence in the data that the political economy factors is an important determinant of a responsiveness a country's trade policy to FTA formation by other countries.

\subsection{Results with 4-digit HS data}

In Tables 6 and 7 we show that our results are robust at higher level of product disaggregation, albeit weakened. Using 3- and 4-digit HS industry classification, we show that tariffs respond negatively to an increase in partner countries' preferential trade. The effect is still the strongest in the second and the third years of a trade agreement but the magnitudes are lower with more disaggregated data. The OLS estimates fall nearly by half when we move from 2-digit to 3-digit industry data, although the IV results with full set of instruments are very close between the two classifications. The coefficient estimates obtained with the 4-digit data are even smaller but remain highly significant in the second and third years of the agreement, confirming our previous findings that FTAs stimulate other countries to lower their tariffs.

\subsection{Trade diversion}

While a decrease in exports of FTA partners to the ROW increases export supply elasticity faced by other countries, the FTA market becomes (relatively) less accessible for goods from non-members which may start exporting relatively more to each other. This trade diversion effect of the FTAs and the following increase in trade between non-members will tend to decrease the elasticity of export supply, which may partially offset the direct effect of an FTA on nonmember tariffs. To test the effect of trade diversion on non-member tariffs, we construct six variables that measure the change in non-member countries' exports to members subsequent to FTA commencement and capture the trade diversion effect:

$$
\begin{gathered}
\Delta T D(T)_{c i t-1}=\left(\sum_{p} i m p \_ \text {share }_{c p i} \cdot \Delta E X P_{-} S H A R E(T)_{p i t-1}\right) \\
\Delta E X P_{-} S H A R E(T)_{p i t-1}=\sum_{j, k \neq c, p} F T A(T)_{k j t} \cdot \Delta_{T} \text { exp_share } e_{p j i t-1}
\end{gathered}
$$

If FTAs cause trade diversion $(\Delta T D(T)<0)$ and deflect trade from non-members to third countries, it would decrease export supply elasticities and increase tariffs of non-member coun- 
tries. Hence, we would expect coefficients on $\Delta T D(T)$ variables to be negative. Results in Table 8 show that only when import shares are instrumented, there is a weak evidence in favor of the effect of trade diversion on trade policies of non-member countries. Most importantly, whether instrumented or not, trade diversion variables have small impact on MFN tariffs and their inclusion does not change the estimates of the $P X S(T)$ effect.

\subsection{Additional robustness tests}

In this subsection we present additional sensitivity tests and tabulate the key estimates for alternative samples of the data. In the first two columns of Table 9 we show that the main result remains qualitatively similar when China is included in the sample. Although rapid increase in Chinese exports in the last twenty years has a strong negative impact on the average change in preferential export share, this effect does not vary systematically across FTAs and keeping China in the sample does not affect the estimates.

Many recent empirical studies on the term-of-trade effect focus only on the non-WTO member countries because tariffs of member countries may no longer reflect the terms of trade motive or reflect it only partially (Bagwell and Staiger, 1999). To test whether trade policies are more responsive to terms-of-trade shocks in the absence of the WTO constraints, we analyze the effect of FTAs on tariffs of the WTO member and non-member countries separately. Focusing on the OLS results, reported in columns (3) and (4) of Table 9, there seem to be no big difference in the estimates for the two groups of countries: while the effect of trade agreements on tariffs is stronger for non-members in the second year, it is not statistically significant in other years. However, comparing the estimates with instrumental variables in columns (5) and (6), the magnitude of the estimated $\beta_{T}$ 's is substantially larger for non-WTO countries, suggesting that import tariffs are more responsive to the terms of trade shocks caused by FTAs when trade policy is not regulated by the WTO rules.

Next, we split the sample by country groups and report results separately for countries with different income levels. The estimates remain statistically significant for both groups of countries, although the magnitudes are greater for developing countries. Finally, in the last two columns we remove African countries from the sample. Most African countries export mostly primary goods and regional integration has little potential for trade creation. Yet there are many multilateral trade agreements in Africa and nearly $15 \%$ of all country-pairs with FTAs in our sample are between African countries. Excluding those trade agreements from the analysis 
does not change any of the results.

\section{Conclusions}

We develop a simple theoretical model of endogenous tariffs with a large number of countries and analyze the effect that the formation of an FTA between a sub-set of them has on the import tariffs of excluded or non-member countries. This model predicts that an FTA redirects export flows of member countries away from the rest of the world towards each other and thereby reduces the elasticities of export supply curves faced by non-members. As a result, the ability of non-members to manipulate their terms-of-trade via import tariffs is weakened which, in turn, induces them to lower their MFN tariffs on FTA members. We show that this trade liberalization effect of an FTA on non-member countries is stronger when the increase in trade flows between members resulting from the agreement is larger.

Bringing this prediction to the data we find considerable support for the hypothesis that FTAs reduce the terms-of-trade motive for protection of non-member countries. Using tariff data for 136 countries and information on all FTAs formed in the world between 1990 and 2011, we find that larger trade flows between member countries indeed lead to reductions in MFN tariffs of their non-member trade partners.

In conclusion, we wish to emphasize two fundamental points. First, since the evidence presented in this paper shows that the formation of FTAs can cause trade liberalization to spillover to excluded countries, an important welfare gain resulting from their formation has been overlooked. For example, the literature addressing whether FTAs are building or stumbling blocs for multilateral liberalization has tended to focus primarily on how FTA formation affects the incentives of member countries to undertake further liberalization with respect to excluded countries. Our analysis shows that we also need to pay attention to the effects that FTAs might have on trade policies of non-member countries. The second major point to note is that our results provide a rather clean and fairly convincing test of the terms of trade theory of trade agreements since the formation of an FTA between a few countries can be reasonably interpreted as an exogenous event from the perspective of the rest of the world. Thus, the paper makes a contribution to the rapidly emerging empirical literature investigating the underpinnings and the key predictions of the terms of trade theory of trade agreements. 


\section{Appendix}

In this section, we provide the necessary supporting calculations, proofs, and discussions.

\subsection{Appendix A. Welfare components and the optimal tariff}

In this section, consistent with the Article XXIV of the GATT, we assume that member countries under an FTA remove their internal tariffs $\left(\widehat{t^{g}}=0\right)$ while imposing external tariffs on the non-member countries independently. As before, suppose that country $z$ forms an FTA with $m$ countries and country $c$ is a non-member country while $\tilde{c}$ denotes non-members other than country $c$. Let $F$ denote the set of FTA member countries. Next, we report individual welfare components for country $c$. Consumer surplus equals

$$
\begin{aligned}
C S_{c}= & \frac{1}{2}\left[\alpha-\frac{n \alpha-2(m+1) t_{m}^{g_{c}}-2(n-m-2) t_{c}^{g_{c}}}{\lambda+2 n}\right]^{2} \\
& +\frac{1}{2} \sum_{j \in F}\left[\alpha-\frac{n \alpha-2 t_{c}^{g_{j}}-2(n-m-2) t_{c}^{g_{j}}}{\lambda+2 n}-t_{c}^{g_{j}}\right]^{2} \\
& +\frac{1}{2} \sum_{j \notin F, j \neq c}\left[\alpha-\frac{n \alpha-2 t_{c}^{g_{j}}-2(m+1) t_{m}^{g_{j}}-(n-m-2) t_{c}^{g_{j}}}{\lambda+2 n}-t_{c}^{g_{j}}\right]^{2}
\end{aligned}
$$

while producer surplus is

$$
\begin{aligned}
P S_{c}= & \frac{1+\lambda}{2}\left[\frac{n \alpha-2(m+1) t_{m}^{g_{c}}-2(n-m-2) t_{c}^{g_{c}}}{\lambda+2 n}\right]^{2} \\
& +\frac{1}{2} \sum_{j \in F}\left[\frac{n \alpha-2 t_{c}^{g_{j}}-2(n-m-2) t_{c}^{g_{j}}}{\lambda+2 n}+t_{c}^{g_{j}}\right]^{2} \\
& +\frac{1}{2} \sum_{j \notin F, j \neq c}\left[\frac{n \alpha-2 t_{c}^{g_{j}}-2(m+1) t_{m}^{g_{j}}-(n-m-2) t_{c}^{g_{j}}}{\lambda+2 n}+t_{c}^{g_{j}}\right]^{2}
\end{aligned}
$$

Furthermore, tariff revenue equals 


$$
\begin{aligned}
& T R_{c}=\frac{\sum_{j \in F} t_{c}^{g_{j}}\left[\alpha \lambda-2 \lambda t_{c}^{g_{j}}-4(n-1) t_{c}^{g_{j}}+4(n-m-2) t_{c^{-}}^{g_{j}}\right]}{\lambda+2 n} \\
& +\frac{\sum_{j \notin F, j \neq c} t_{c}^{g_{j}}\left[\alpha \lambda-2 \lambda t_{c}^{g_{j}}-4(n-1) t_{c}^{g_{j}}+4(m+1) t_{m}^{g_{j}}+4(n-m-3) t_{c^{-}}^{g_{j}}\right]}{\lambda+2 n}
\end{aligned}
$$

Under optimal tariffs, the export supply elasticity $\varepsilon_{c}^{g_{z}}$ is found as:

$$
\varepsilon_{c}^{g_{z}}=\frac{n \lambda+2[n(n-1)+m+1]}{\lambda}
$$

Note that the intensive margin is internalized with optimal tariffs and only extensive margin appears in capturing the preferential export share. The formation of an FTA raises $\varepsilon_{c}^{g_{z}}$ relative to no agreement and it rises more as the FTA has more members (as the preferential export share rises): $\frac{\partial \varepsilon_{c}^{g z}}{\partial m}>0$. Country $c$ 's optimum external tariff on good $g_{z}$ is found as follows:

$$
t_{c}^{g_{z}}=\frac{\alpha \lambda}{(\lambda+2 n)^{2}-4(n-m-1)}
$$

Consistent with the export supply elasticity discussion, we find that non-member countries impose lower tariffs with the formation of an FTA and as the size of the FTA expands (i.e. as the preferential export share of a typical FTA member rises), the result gets stronger: $\frac{\partial t_{c}^{g_{z}}}{\partial m}<0$.

\subsection{Appendix B. General demand and supply}

In this section, we examine whether the results obtained under a linear demand and supply framework extend to a more general setting. To this end, we make two fairly unobjectionable assumptions: (i) import demand functions are negatively sloped while export supply functions are positively sloped ; (ii) there exist at least one member country exporting good $z$ while at least one other member country and one non-member country (country $c$ ) importing good $g_{z}$. At a given world price, the formation of an FTA increases the preferential export shares of member countries while simultaneously reducing their export supply to all importing nonmember countries. As a result, FTA formation leads to a decrease in $x_{z c}^{g_{z}}\left(p_{z}^{g_{z}}\right)$, shifting it parallel leftward and the equilibrium world price of good $g_{z}$ rises while the equilibrium exports of good $g_{z}$ to country $c$ fall. ${ }^{14}$ Note that the larger the volume of preferential trade among FTA members relative to the rest of the world, the greater the magnitude of the leftward shift of $x_{z c}^{g_{z}}\left(p_{z}^{g_{z}}\right)$.

\footnotetext{
${ }^{14}$ The same results would obtain even when the shift is non-parallel as long as there is a greater magnitude of shift at higher prices.
} 
The following result, confirms that the main findings of our theoretical model hold under a fairly general setting:

Proposition 2: Suppose that the (inverse) export supply function $p_{z}^{g_{z}}\left(x_{z c}^{g_{z}}\right)$ is log-concave. ${ }^{15}$ Then the following holds: (i) the formation of an FTA raises $\varepsilon_{c}^{g_{z}}$ which in turn leads to a reduction in the optimal tariff $t_{c}^{g_{z}}$ of a typical non-member country (i.e. country c) and (ii) the larger the increase in the volume of preferential trade among FTA members relative to the rest of the world, the larger is the reduction in the tariffs of non-member countries.

As mentioned above, following the formation of an FTA, the export supply curve of country $z$, i.e. $x_{z c}^{g_{z}^{0}}\left(p_{z}^{g_{z}}\right)$, shifts parallel leftward to $x_{z c}^{g_{z}^{\prime}}\left(p_{z}^{g_{z}}\right)$. As represented in figure 1 , at the original equilibrium price $p_{z}^{g_{z}^{0}}$, the outputs supplied are $x_{z c}^{g_{z}^{0}}$ and $\widetilde{x_{z c}^{g_{z}}}$ along the supply curves $x_{z c}^{g_{z}^{0}}\left(p_{z}^{g_{z}}\right)$ and $x_{z c}^{g_{z}^{\prime}}\left(p_{z}^{g_{z}}\right)$, respectively. ${ }^{16}$ Note that we have the same slope at $p_{z}^{g_{z}^{0}}$ along both $x_{z c}^{g_{z}^{0}}\left(p_{z}^{g_{z}}\right)$ and $x_{z c}^{g_{z}^{\prime}}\left(p_{z}^{g_{z}}\right)$ and thus $\frac{d x_{z c}^{g_{z}}}{d p_{z}^{g_{z}}\left(x_{z c}^{\left.g_{z}\right)}\right.} p_{z}^{g_{z}}$ is the same at both $x_{z c}^{g_{z}^{0}}$ and $\widetilde{x_{z c}^{g_{z}}}$. Furthermore, the new equilibrium quantity of exports $\left(x_{z c}^{g_{z}^{\prime}}\right)$ is smaller relative to the original $\left(x_{z c}^{g_{z}^{0}}\right): x_{z c}^{g_{z}^{\prime}}<x_{z c}^{g_{z}^{0}}$. Since the inverse export supply function is log-concave, moving from $\widetilde{x_{z c}^{g_{z}}}$ to new equilibrium export supplied $x_{z c}^{g_{z}^{\prime}}$, $\frac{d x_{z c}^{g_{z}}}{d p_{z}^{g z}\left(x_{z c}^{g}\right)} p_{z}^{g_{z}}$ rises. As a result, the export supply elasticity at $x_{z c}^{g_{z}^{\prime}}$ is larger than that at $x_{z c}^{g_{z}^{0}}$ which in turn induces the non-member country $c$ to reduce its optimal tariff $t_{c}^{g_{z}}$. Finally, the larger the increase in the volume of preferential trade among FTA members relative to the rest of the world, the greater the magnitude of the leftward shift in the export supply curve $x_{z c}^{g_{z}^{0}}\left(p_{z}^{g_{z}}\right)$ of member country $z$ and larger the increase in the export supply elasticity facing non-members.

- Figure $1-$

\subsection{Appendix C. Relationship between changes in export supply elasticities and preferential export shares}

In the main text we emphasize one key assumption required for the identification of the effect of FTAs on import tariffs of excluded countries using explanatory variables (28) and instruments

\footnotetext{
${ }^{15}$ Note from its definition that $p_{z}^{g_{z}}\left(x_{z c}^{g_{z}}\right)$ is log-concave if and only if $\frac{d^{2} \log p_{z}^{g_{z}}\left(x_{z c}^{g z}\right)}{d x_{z c}^{g_{z}}}<0$ holds. This condition implies that $\frac{d p_{z}^{g}\left(x_{z c}^{g}\right)}{\left.d x_{z c}^{g}\right)} \frac{1}{p_{z}^{g}}$ falls as $x_{z c}^{g_{z}}$ rises or we can rearrange and argue that $\frac{d x_{z c}^{g}}{d p_{z}^{g}\left(x_{z c}^{g}\right)} p_{z}^{g_{z}}$ rises as $x_{z c}^{g_{z}}$ rises. It is important to note that log-concavity of the inverse export supply function is the sufficient but not the necessary condition for our result.

${ }^{16}$ Note that when the inverse export supply function is concave or linear, log-concavity always holds. Therefore, we represent only the case of strictly convex inverse export supply in our figure.
} 
(31) in the model (29). Specifically, the variation in the trade-weighted average of the preferential export share of a country's trade partners should reflect the variation in the export supply elasticity. In this Appendix we provide some evidence in support of this assumption. We do so by estimating export supply elasticities for every country-industry pair in our sample for two time periods and relating the change in the elasticity to the observed change in preferential export shares of a country's average trade partner.

We use the approach of Feenstra (1994) and its extension by Broda and Weinstein (2006) to separately identify import demand and export supply elasticities. The presentation here draws heavily on the treatment in Broda and Weinstein (2006), which can be used for a more detailed reference. The approach is based on the following parametrization of the system of import demand and export supply equations:

$$
\begin{aligned}
& x_{c i v t}=\left(\frac{p_{c i v t}}{\phi_{i t}}\right)^{1-\sigma_{c i}} \frac{d_{c i v t} E_{c t}}{p_{c i v t}} \\
& p_{c i v t}=\exp \left(v_{c i v t}\right) x_{c i v t}^{\omega_{c i}}
\end{aligned}
$$

where $x_{\text {civt }}$ in the first equation is the demand for variety $v$ of good $i$ consumed in country $c$ in year $t$ derived from the CES utility function which depends on the price $\left(p_{\text {civt }}\right)$, aggregate income $\left(E_{c t}\right)$, the elasticity of substitution between varieties of good $i\left(\sigma_{c i}\right)$, price index for good $i\left(\phi_{i t}\right)$, and the random taste parameter $\left(d_{c i v t}\right)$. The export supply function depends on the inverse export supply elasticity $\left(\omega_{c i}\right)$ and the random technology factor $\left(v_{\text {civt }}\right)$ assumed to be independent of $d_{c i v t}$. Re-writing quantities in (36) in terms of market shares, taking logs, and time differencing yields

$$
\begin{aligned}
& \Delta \ln s_{\text {civt }}=\varphi_{i t}-\left(\sigma_{c i}-1\right) \Delta \ln p_{\text {civt }}+u_{\text {civt }} \\
& \Delta \ln p_{\text {civt }}=\omega_{c i} \Delta \ln x_{\text {civt }}+\delta_{\text {civt }}
\end{aligned}
$$

where $\varphi_{i t}=\left(\sigma_{c i}-1\right) \ln \left[\phi_{i t} / \phi_{i t-1}\right]$. In order to eliminate this good-specific unobservable term from the demand equation, both equation are differences with respect to a reference country $k$. Using superscript $k$ to denote the reference difference operator, the system becomes

$$
\begin{aligned}
\Delta^{k} \ln s_{c i v t} & =-\left(\sigma_{c i}-1\right) \Delta^{k} \ln p_{c i v t}+u_{c i v t}^{k} \\
\Delta^{k} \ln p_{c i v t} & =\omega_{c i} \Delta^{k} \ln x_{c i v t}+\delta_{c i v t}^{k}
\end{aligned}
$$


Solving for the error terms in (37) and multiplying them through, we obtain:

$$
\begin{aligned}
& Y_{\text {civt }}=\theta_{1 c i} X_{1 c i v t}+\theta_{2 c i} X_{2 c i v t}+u_{c i v t} \\
& Y_{\text {civt }}=\left(\Delta^{k} \ln p_{\text {civt }}\right)^{2}, X_{1 c i v t}=\left(\Delta^{k} \ln s_{\text {civt }}\right)^{2}, X_{2 c i v t}=\left(\Delta^{k} \ln p_{\text {civt }}\right)\left(\Delta^{k} \ln s_{\text {civt }}\right) \\
& u_{c i v t}=\frac{u_{c i v t}^{k} \delta_{c i v t}^{k}}{\left(1-\rho_{c i}\right)}, \rho_{c i}=\frac{\omega_{c i}\left(\sigma_{c i}-1\right)}{1+\omega_{c i} \sigma_{c i}}
\end{aligned}
$$

Feenstra (1994) demonstrates that equation (38) estimated with the 2SLS for every country and industry using indicator variables for varieties as instruments will produce consistent estimates of $\theta_{1 c i}$ and $\theta_{2 c i}$. This estimates, $\widehat{\theta}_{1 c i}$ and $\widehat{\theta}_{2 c i}$, can be used to calculate elasticity parameters from

$$
\begin{aligned}
\widehat{\theta}_{1 c i} & =\frac{\widehat{\omega}_{c i}}{\left(1+\widehat{\omega}_{c i}\right)\left(\widehat{\sigma}_{c i}-1\right)} \\
\widehat{\theta}_{2 c i} & =\frac{\widehat{\omega}_{c i}\left(\widehat{\sigma}_{c i}-2\right)-1}{\left(1+\widehat{\omega}_{c i}\right)\left(\widehat{\sigma}_{c i}-1\right)}
\end{aligned}
$$

The identification of import demand and export supply elasticities in Feenstra (1994) rests on a number of strong assumptions which make it impossible to use them directly in our work. Most importantly for this study, the estimator is asymptotically consistent as the number of time periods approaches infinity. Therefore, changes in the elasticities cannot be obtained for every country-industry-year observation in our sample and are proxied by changes in preferential export shares. In order to assess the quality of this proxy we need to obtain a measure of a change in the export supply elasticity that can be related to changes in preferential export shares. We thus proceed by estimating export supply elasticity $\omega_{c i}$ for every country-industry pair in two time periods, 1988-2001 and 2002-2011. Denoting the two periods with $T_{1}$ and $T_{2}$, we then calculate the change in the average preferential export share between the two periods and regress it on the change in the inverse export supply elasticity: ${ }^{17}$

$$
\begin{aligned}
\Delta \overline{P X S}_{c i} & =\beta_{0}+\beta_{1} \Delta \omega_{c i}+e_{c i} \\
\overline{P X S}_{c i T_{k}} & =\left(\frac{1}{T_{k}} \sum_{p} i m p \_ \text {share }_{c p i} \cdot \sum_{t \in T_{k}} \Delta P R E F_{-} S H A R E_{p i t}\right), k=1,2 \\
\Delta \overline{P X S}_{c i} & =\overline{P X S}_{c i T_{2}}-\overline{P X S}_{c i T_{1}}, \Delta \omega_{c i}=\omega_{c i T_{2}}-\omega_{c i T_{1}}
\end{aligned}
$$

Table A1 presents estimation results for equation (40). The coefficient in column (1) is negative and statistically significant at 5\% confidence level. This result implies that, as the theory

\footnotetext{
${ }^{17}$ In this regression we use only observations with $\widehat{\theta}_{1 c i}>0$. We also drop one percent of the observations with the highest and the lowest changes in $\omega_{c i}$ in order to minimize the effect of outliers.
} 
predicts, a reduction in the inverse export supply elasticity (increase in the level of the export supply elasticity) is associated with an increase in the preferential export share of a country's trade partners. Adding industry fixed effects in column (2) to control for industry-specific trends in preferential trade shares does not affect the results. Column (3) includes country fixed effects to control for country-year specific characteristics such as size and the general structure of trade. Results are broadly similar to the basic specification. Finally, in columns (4)-(6) we reestimate equation (40) using only FTAs formed in 2001-2002 in construction of the dependent variable. These are the FTA which do not affect the estimate of $\omega_{c i}$ in period $T_{1}$ and have potentially the strongest impact on $\omega_{c i}$ in period $T_{2}$. Although the coefficient $\beta_{1}$ is smaller than in columns (1)-(3), it becomes statistically significant at $1 \%$ confidence level. ${ }^{18}$

While the above evidence is consistent with our assumption that changes in preferential export shares reflect changes in the export supply elasticities, these results should be treated with caution. The average number of time periods in the two subsamples are 6.4 and 7.1, respectively, and the estimates of $\omega_{c i T_{2}}$ and $\omega_{c i T_{1}}$ may not be very precise. Indeed, Soderbery (2010) show that in samples of that size the estimates of the export supply elasticity are biased upward by more than $60 \%$.

\subsection{Appendix D. Instrumenting preferential export shares}

This appendix provides a detailed description of instruments for preferential export shares used in the estimation. Instrumenting changes in preferential export shares requires IVs which are correlated with the effect of a trade agreement on trade flows between member countries but uncorrelated with either MFN tariffs of third countries or with the common shocks. Our IV strategy is motivated by Baier and Bergstrand (2004) who constructed a general equilibrium model of trade with two monopolistically competitive industries, two factors of production, six countries, and three continents. Using this model, Baier and Bergstrand identify several factors which contribute to larger effect of an FTA on trade volumes between member countries. Specifically, they find that FTAs lead to more trade between member countries when trade partners are 'natural' (i.e. when trade costs between them are low), more remote from the rest of the world, and larger and more similar in size. They also show that FTAs create more trade when the difference in factor endowments is large between member countries and small between members and the rest of the world. As with the instrumental variables strategy

\footnotetext{
${ }^{18}$ The variation in $\Delta \overline{P P X}_{c i}$ in columns (4)-(6) is only one sixth of that in columns (1)-(3). For both dependent variables the change in $\omega_{c i}$ explains the same share of variation.
} 
for import shares, we begin by focusing on geographic determinants of trade only, and add differences in factor endowments in our analysis later.

To control for trade costs between FTA member countries $p$ and $j$ we use three gravity model variables: logarithm of the bilateral distance $\left(\ln D_{p j}\right)$, common border indicator $\left(B_{p j}\right)$, and common language indicator $\left(L_{p j}\right)$. The remoteness measure for a pair of countries $p$ and $j$ with respect to the rest of the world is constructed as the simple average of the log of mean distance of country $p$ to its trade partners except for $j$ and the log of mean distance of country $j$ to its trade partners except for $p$ :

$$
R E M O T E_{p j}=\frac{1}{2}\left[\ln \left(\frac{\sum_{n \neq j} D_{p k}}{N-2}\right)+\ln \left(\frac{\sum_{n \neq p} D_{j k}}{N-2}\right)\right]
$$

where $D_{p n}$ is the distance between countries $p$ and $n$ and $N$ is the total number of countries. As in Baier and Bergstrand, we use the interaction of the remoteness measure with the same continent indicator variable $\left(C R E M O T E_{p j}\right)$ in order to distinguish intercontinental and intracontinental trade costs. We use the sum of logarithms of two countries' populations as a measure of their economic size $\left(S I Z E_{p j}\right)$ and the absolute difference in the logarithms of population of two countries as a measure of size asymmetry $\left(D S I Z E_{p j}\right)$.

Because we need instruments for preferential export shares at country-pair-industry-year level while the geography variables do not vary within country pair cells, our point of departure is to estimate the dynamic effect of those variables on trade volumes within an FTA. We allow several years for trade volumes between trade partners to converge to new equilibrium levels after the FTA is established. There are at least two reasons to expect a delayed response of trade flows to FTA formation. First, it may take some time for producers to adjust their production plans and capacities to changes in market conditions. Second, many FTAs do not lead to free trade in the first year of the agreement but rather liberalize trade policy gradually by phasingout preferential tariff reductions over several years. In the presence of dynamic response of trade flows to FTA formation, we allow for the effect of the instruments for preferential trade shares to be time-specific during the first five years of the agreement.

Let $F T A(T)_{p j t}$ to be an indicator variable which is equal to one if countries $p$ and $j$ entered an FTA in year $(t-T)$ for $T \leq 5{ }^{19}$ For every industry $i$ we estimate the following regression:

$$
\begin{aligned}
\Delta_{T} \exp \_ \text {share }_{p j i t}= & \beta_{i T}^{0}+\beta_{i T}^{1} \ln D_{p j t}^{T}+\beta_{i T}^{2} B_{p j t}^{T}+\beta_{i T}^{3} L_{p j t}^{T}+ \\
& +\beta_{i T}^{4} \operatorname{REMOTE}_{p j t}^{T}+\beta_{i T}^{5} C R E M O T E_{p j t}^{T}+ \\
& +\beta_{i T}^{6} \text { SIZ }_{p j}+\beta_{i T}^{7} D S I Z E_{p j}+v_{p j i t}
\end{aligned}
$$

\footnotetext{
${ }^{19}$ The last category, $F T A(6)_{p j t}$, aggregates all FTAs formed in years $(t-6)$ and before.
} 
where $x_{p j t}^{T}=F T A(T)_{p j t} x_{p j}$. Having estimated equation (41) for every industry, we obtain the predicted change in the preferential export share between years $t$ and $(t-T)$ for every country-pair, industry and year, $\Delta_{T}$ exp_share $e_{p j i t}$.

Three points about equation (41) need to be emphasized. First, allowing for the effect of FTAs to be dynamic generates variation in $\Delta_{T}$ exp_share ${ }_{p j i t}$ over time. Second, with the coefficients on the right-hand side variables varying by industry we obtain cross-industry variation in the predicted preferential trade shares even though the variation in geography variables in (41) is by country-pair. To develop intuition for this approach, consider the distance variable. We know that the effect of an FTA on trade flows depends on trade costs and is decreasing in distance. Our earlier results also show that the effect of distance and other gravity model measures of trade costs vary across industries. Therefore, we would expect the effect of FTA on trade to be stronger in those industries where transportation costs and distance play lesser role. The relevance of variation in coefficients in equation (41) is supported by the fact that $65 \%$ of variation in $\Delta_{T}$ exp_shar $e_{p j i t}$ is coming from the variation within country-pair-year cells and $51 \%$ is coming from the variation within country-pair-industry cells. Lastly, we are not trying to predict changes in preferential trade between countries which are not members of any preferential trade agreement. For this reason, equation (41) is estimated only for country pairs which were part of an FTA in year $(t-1)$, i.e. we only use observations for which the dependent variable is different from zero.

Using the model (41), we reject the null that trade costs, remoteness, and size variables have no effect on changes in preferential export shares for 94 industries out of 97 at $1 \%$ confidence level. For the remaining 3 industries the explanatory variables in (41) are jointly significant at $5 \%$. The mean F-statistics for the test $\beta_{i T}^{k}=0 \forall k=1, . .7$ is 9.26 , the mean R-square is 0.21 , and the correlation between predicted and actual preferential trade shares is 0.31 . These results suggest that trade costs, remoteness, and the level and asymmetry in population of two countries can be used to predict the effect of an FTA on preferential trade shares. Using these geographic characteristics of a pair of FTA member countries allows us to construct a measure of preferential trade shares which are plausibly independent from trade policies of third countries.

Our second instrument for $\Delta_{T}$ exp_share $p_{p j i t}$ isolates variation in preferential export shares stemming from differences in factor endowments across FTA member states. Baier and Bergstrand's model predicts that FTAs create more trade when the difference in factor endowments is large 
between member countries. Using this insight, we modify equation (41) as follows:

$$
\begin{aligned}
\Delta_{T} e_{-} \text {share }_{p j i t}= & \beta_{i T}^{0}+\beta_{i T}^{1} \ln D_{p j t}^{T}+\beta_{i T}^{2} B_{p j t}^{T}+\beta_{i T}^{3} L_{p j t}^{T}+\beta_{i T}^{4} R_{E M O T E_{p j t}^{T}} \\
& +\beta_{i T}^{5} C R E M O T E_{p j t}^{T}+\beta_{i T}^{6} S I Z E_{p j}+\beta_{i T}^{7} D S I Z E_{p j}+ \\
& +\beta_{i T}^{8} \bar{K}_{p j t}+\beta_{i T}^{9} \bar{H}_{p j t}+\beta_{i T}^{10} P M_{p j i t}+ \\
& +\beta_{i T}^{11} \bar{K}_{p j t} \times P M_{p j i t}+\beta_{i T}^{12} \bar{H}_{p j t} \times P M_{p j i t}+v_{p j i t}
\end{aligned}
$$

where $\bar{K}_{p j t}$ is the difference in physical capital endowments of countries $p$ and $j$ at time $t, \bar{H}_{p j t}$ is the difference in human capital endowments, and $P M_{p j i t}$ is the preference margin defined as the difference between the MFN tariff of country $p$ and the preferential tariff that country $p$ applies to imports from country $j$. We also include interactions of $\bar{K}_{p j t}$ and $\bar{H}_{p j t}$ with the importer's preference margin to capture the possibility that factor endowment differences may have stronger impact on trade when tariff concessions are deeper. Using the estimates from equation (42) we construct two sets of instruments, $I V 2(T)$ and $I V 3(T)$, which isolate geographic factor endowment determinants of changes in preferential export shares:

$$
\begin{aligned}
& I V 2(T)_{c i t-1}=\left(\sum_{p} \mathrm{imp \_ share}_{c p i} \cdot \sum_{j \neq c} F T A(T)_{p j t} \cdot \Delta_{T} \text { exp_share } 1_{p j i t-1}\right) \\
& I V 3(T)_{c i t-1}=\left(\sum_{p} \widehat{i m p \_s h a r e}{ }_{c p i} \cdot \sum_{j \neq c} F T A(T)_{p j t} \cdot \Delta_{T} \text { exp_share } 2_{p j i t-1}\right) \\
& \Delta_{T} \text { exp_share } 1_{p j i t-1}=\widehat{\beta}_{i T}^{1} \ln D_{p j t}^{T}+\widehat{\beta}_{i T}^{2} B_{p j t}^{T}+\widehat{\beta}_{i T}^{3} L_{p j t}^{T}+\widehat{\beta}_{i T}^{4} R E M O T E_{p j t}^{T}+ \\
& +\widehat{\beta}_{i T}^{5} C R E M O T E_{p j t}^{T}+\widehat{\beta}_{i T}^{6} S I Z E_{p j}+\widehat{\beta}_{i T}^{7} D S I Z E_{p j} \\
& \Delta_{T} \text { exp_share } 1_{p j i t-1}=\widehat{\beta}_{i T}^{8} \bar{K}_{p j t}+\widehat{\beta}_{i T}^{9} \bar{H}_{p j t}+\widehat{\beta}_{i T}^{10} P M_{p j i t}+\widehat{\beta}_{i T}^{11} \bar{K}_{p j t} \times P M_{p j i t}+\widehat{\beta}_{i T}^{12} \bar{H}_{p j t} \times P M_{p j i t}
\end{aligned}
$$

Data on country's stock of physical capital, measured in constant 2005 prices, is retrieved from the Penn World Table. Human capital stock is obtained from Barro and Lee (2013) and is measured as a share of population with secondary and tertiary education. 


\section{References}

Angrist, J. D., And J.-S. Pischke (2009): Mostly Harmless Econometrics: An Empiricist's Companion. Princeton University Press.

Bagwell, K., and R. W. Staiger (1990): "A Theory of Managed Trade," American Economic Review, 80(4), 779-95.

(1997): "Multilateral Tariff Cooperation during the Formation of Free Trade Areas," International Economic Review, 38(2), 291-319.

Bagwell, K., and R. W. Staiger (1999): "An Economic Theory of GATT," American Economic Review, 89(1), 215-248.

(2009): Regionalism and Multilateral Tariff Cooperation. in John Piggott and Allan Woodland, eds, International Trade Policy and the Pacific Rim, London: MacMillan.

(2011): "What Do Trade Negotiators Negotiate About? Empirical Evidence from the World Trade Organization," American Economic Review, 101(4), 1238-73.

BAier, S. L., And J. H. Bergstrand (2004): "Economic determinants of free trade agreements," Journal of International Economics, 64(1), 29-63.

Barro, R. J., AND J. W. LEE (2013): "A new data set of educational attainment in the world, 1950Ü2010," Journal of Development Economics, 104(C), 184-198.

Bohara, A. K., K. Gawande, and P. Sanguinetti (2004): "Trade diversion and declining tariffs: evidence from Mercosur," Journal of International Economics, 64(1), 65-88.

Bown, C. P., And M. A. Crowley (2013): "Self-Enforcing Trade Agreements: Evidence from Time-Varying Trade Policy," American Economic Review, 103(2), 1071-90.

Broda, C., N. Limão, and D. E. Weinstein (2008): "Optimal Tariffs and Market Power: The Evidence," American Economic Review, 98(5), 2032-65.

Broda, C., and D. E. Weinstein (2006): "Globalization and the Gains from Variety," The Quarterly Journal of Economics, 121(2), 541-585.

Calvo-Pardo, H., C. Freund, and E. Ornelas (2009): "The ASEAN Free Trade Agreement: Impact on Trade Flows and External Trade Barriers," CEP Discussion Papers dp0930, Centre for Economic Performance, LSE. 
Do, Q.-T., And A. A. Levchenko (2007): "Comparative advantage, demand for external finance, and financial development," Journal of Financial Economics, 86(3), 796-834.

Estevadeordal, A., C. Freund, and E. Ornelas (2008): "Does Regionalism Affect Trade Liberalization toward NonMembers?," The Quarterly Journal of Economics, 123(4), 15311575 .

Feenstra, R. (2004): Advanced International Trade. Princeton University Press.

Feenstra, R. C. (1994): "New Product Varieties and the Measurement of International Prices," American Economic Review, 84(1), 157-77.

Frankel, J. A., And D. H. Romer (1999): "Does Trade Cause Growth?," American Economic Review, 89(3), 379-399.

Gawande, K., P. Krishna, and M. Olarreaga (2009): "What Governments Maximize and Why: The View from Trade," International Organization, 63(03), 491-532.

Grossman, G. M., and E. Helpman (1994): "Protection for Sale," American Economic Review, 84(4), 833-50.

Hillberry, R., and D. Hummels (2013): Trade Elasticity Parameters for a Computable General Equilibrium Model, vol. 1. Handbook of Computable General Equilibrium Modeling, Elsevier.

Horn, H., G. Maggi, and R. W. Staiger (2010): "Trade Agreements as Endogenously Incomplete Contracts," American Economic Review, 100(1), 394-419.

Krishna, P. (1998): "Regionalism And Multilateralism: A Political Economy Approach," The Quarterly Journal of Economics, 113(1), 227-250.

Limão, N. (2006): "Preferential Trade Agreements as Stumbling Blocks for Multilateral Trade Liberalization: Evidence for the United States," American Economic Review, 96(3), 896-914.

Ludema, R. D., And A. M. Mayda (2013): "Do terms-of-trade effects matter for trade agreements? Theory and evidence from WTO Countries," The Quarterly Journal of Economics, $128(4), 1837-1893$.

Maggi, G. (2014): International Trade Agreements. in G. Gopinath, E. Helpman and K. Rogoff, The Handbook of International Economics, Elsevier. 
Soderbery, A. (2010): "Investigating the asymptotic properties of import elasticity estimates," Economics Letters, 109(2), 57-62.

Staiger, D., and J. H. Stock (1997): "Instrumental Variables Regression with Weak Instruments," Econometrica, 65(3), 557-586. 
Table 1 . Summary statistics

\begin{tabular}{lcccccc}
\hline & Mean & Median & St.dev. & Minimum & Maximum & NOB \\
\hline MFN & 11.89 & 9.33 & 18.34 & 0 & 330.6 & 122,908 \\
$\Delta$ MFN & -0.21 & 0 & 4.53 & -146 & 128.3 & 83,506 \\
$\Delta$ ma & -0.07 & -0.03 & 0.28 & -4.78 & 3.36 & 124,805 \\
$\Delta \mathrm{PXS}(\mathrm{T}=1)$ & -0.03 & 0 & 1.09 & -50.54 & 36.34 & 124,805 \\
$\Delta \mathrm{PXS}(\mathrm{T}=2)$ & -0.03 & 0 & 1.00 & -53.71 & 45.97 & 124,805 \\
$\Delta \mathrm{PXS}(\mathrm{T}=3)$ & -0.01 & 0 & 0.93 & -37.49 & 54.68 & 124,805 \\
$\Delta \mathrm{PXS}(\mathrm{T}=4)$ & -0.04 & 0 & 1.07 & -61.4 & 36.88 & 124,805 \\
$\Delta \mathrm{PXS}(\mathrm{T}=5)$ & -0.01 & 0 & 1.32 & -55.17 & 46.25 & 124,805 \\
$\Delta \mathrm{PXS}(\mathrm{T}>5)$ & -0.24 & 0 & 2.36 & -66.8 & 61.9 & 124,805 \\
\hline
\end{tabular}

Table 2. OLS results

\begin{tabular}{|c|c|c|c|c|c|}
\hline & (1) & $(2)$ & (3) & (4) & $(5)$ \\
\hline $\operatorname{PXS}(\mathrm{T}=1)$ & $\begin{array}{c}-0.064^{* * *} \\
(0.017)\end{array}$ & $\begin{array}{c}-0.055^{* * *} \\
(0.018)\end{array}$ & $\begin{array}{c}-0.038^{* *} \\
(0.018)\end{array}$ & $\begin{array}{c}-0.033^{*} \\
(0.018)\end{array}$ & $\begin{array}{c}-0.038^{* *} \\
(0.018)\end{array}$ \\
\hline $\operatorname{PXS}(\mathrm{T}=2)$ & $\begin{array}{c}-0.018 \\
(0.014)\end{array}$ & $\begin{array}{c}-0.042^{* * *} \\
(0.014)\end{array}$ & $\begin{array}{c}-0.048^{* * *} \\
(0.014)\end{array}$ & $\begin{array}{c}-0.047^{* * *} \\
(0.015)\end{array}$ & $\begin{array}{c}-0.047^{* * *} \\
(0.014)\end{array}$ \\
\hline $\operatorname{PXS}(\mathrm{T}=3)$ & $\begin{array}{c}-0.045^{* * *} \\
(0.015)\end{array}$ & $\begin{array}{c}-0.038^{* * *} \\
(0.014)\end{array}$ & $\begin{array}{c}-0.030^{* *} \\
(0.013)\end{array}$ & $\begin{array}{c}-0.030^{* *} \\
(0.013)\end{array}$ & $\begin{array}{c}-0.030^{* *} \\
(0.013)\end{array}$ \\
\hline $\operatorname{PXS}(\mathrm{T}=4)$ & $\begin{array}{c}-0.032^{* *} \\
(0.015)\end{array}$ & $\begin{array}{c}-0.034^{* *} \\
(0.015)\end{array}$ & $\begin{array}{c}-0.015 \\
(0.014)\end{array}$ & $\begin{array}{c}-0.018 \\
(0.014)\end{array}$ & $\begin{array}{c}-0.015 \\
(0.014)\end{array}$ \\
\hline $\operatorname{PXS}(\mathrm{T}=5)$ & $\begin{array}{c}0.011 \\
(0.016)\end{array}$ & $\begin{array}{c}-0.011 \\
(0.015)\end{array}$ & $\begin{array}{c}-0.013 \\
(0.015)\end{array}$ & $\begin{array}{c}-0.014 \\
(0.015)\end{array}$ & $\begin{array}{c}-0.014 \\
(0.015)\end{array}$ \\
\hline $\operatorname{PXS}(\mathrm{T}>5)$ & $\begin{array}{c}0.014^{*} \\
(0.008)\end{array}$ & $\begin{array}{c}0.004 \\
(0.008)\end{array}$ & $\begin{array}{c}0.011 \\
(0.009)\end{array}$ & $\begin{array}{c}0.010 \\
(0.009)\end{array}$ & $\begin{array}{c}0.011 \\
(0.009)\end{array}$ \\
\hline Constant & $\begin{array}{c}-0.005^{* * *} \\
(0.000)\end{array}$ & $\begin{array}{c}-0.005^{* * *} \\
(0.000)\end{array}$ & $\begin{array}{c}-0.002^{* * *} \\
(0.000)\end{array}$ & $\begin{array}{c}-0.003^{* *} \\
(0.002)\end{array}$ & $\begin{array}{c}-0.002^{* * *} \\
(0.000)\end{array}$ \\
\hline Country-Year FE & NO & YES & YES & YES & YES \\
\hline Country-industry FE & NO & NO & YES & YES & YES \\
\hline Industry-year FE & NO & NO & NO & YES & NO \\
\hline $\begin{array}{l}\text { Control for } \\
\text { reciprocity }\end{array}$ & NO & NO & NO & NO & YES \\
\hline R-squared & 0.001 & 0.140 & 0.242 & 0.242 & 0.242 \\
\hline $\mathrm{N}$ & 51,299 & 51,299 & 51,299 & 51,299 & 51,299 \\
\hline
\end{tabular}


Table 3. OLS results with explanatory variables decomposed into positive and negative terms

\begin{tabular}{|c|c|c|c|c|c|c|c|c|}
\hline & \multicolumn{2}{|c|}{ (1) } & \multicolumn{2}{|c|}{ (2) } & \multicolumn{2}{|c|}{ (3) } & \multicolumn{2}{|c|}{ (4) } \\
\hline & $\begin{array}{c}(\mathrm{a}) \\
\mathrm{PXS}(\mathrm{T})^{\mathrm{P}}\end{array}$ & $\begin{array}{c}\text { (b) } \\
\operatorname{PXS}(T)^{N}\end{array}$ & $\begin{array}{c}\text { (a) } \\
\text { PXS(T) }\end{array}$ & $\begin{array}{c}\text { (b) } \\
\operatorname{PXS}(T)^{N}\end{array}$ & $\begin{array}{c}(\mathrm{a}) \\
\operatorname{PXS}(\mathrm{T})^{\mathrm{P}}\end{array}$ & $\begin{array}{c}\text { (b) } \\
\operatorname{PXS}(T)^{N}\end{array}$ & $\begin{array}{c}\text { (a) } \\
\text { PXS(T) }\end{array}$ & $\begin{array}{c}\text { (b) } \\
\operatorname{PXS}(T)^{N}\end{array}$ \\
\hline $\mathrm{T}=1$ & $\begin{array}{c}-0.071^{* * *} \\
(0.025)\end{array}$ & $\begin{array}{c}-0.068^{* * *} \\
(0.023)\end{array}$ & $\begin{array}{c}-0.080^{* * *} \\
(0.027)\end{array}$ & $\begin{array}{c}-0.025 \\
(0.027)\end{array}$ & $\begin{array}{c}-0.095^{* * *} \\
(0.026)\end{array}$ & $\begin{array}{c}0.002 \\
(0.030)\end{array}$ & $\begin{array}{c}-0.089 * * * \\
(0.026)\end{array}$ & $\begin{array}{c}0.010 \\
(0.030)\end{array}$ \\
\hline $\mathrm{T}=2$ & $\begin{array}{c}0.014 \\
(0.026)\end{array}$ & $\begin{array}{c}0.013 \\
(0.017)\end{array}$ & $\begin{array}{l}-0.028 \\
(0.026)\end{array}$ & $\begin{array}{c}-0.014 \\
(0.019)\end{array}$ & $\begin{array}{l}-0.032 \\
(0.023)\end{array}$ & $\begin{array}{l}-0.019 \\
(0.019)\end{array}$ & $\begin{array}{c}-0.030 \\
(0.023)\end{array}$ & $\begin{array}{l}-0.026 \\
(0.020)\end{array}$ \\
\hline $\mathrm{T}=3$ & $\begin{array}{c}-0.014 \\
(0.023)\end{array}$ & $\begin{array}{c}-0.044^{* *} \\
(0.017)\end{array}$ & $\begin{array}{l}-0.040^{*} \\
(0.023)\end{array}$ & $\begin{array}{c}0.001 \\
(0.019)\end{array}$ & $\begin{array}{c}-0.053^{* *} \\
(0.022)\end{array}$ & $\begin{array}{c}0.001 \\
(0.017)\end{array}$ & $\begin{array}{c}-0.052^{* *} \\
(0.022)\end{array}$ & $\begin{array}{c}0.012 \\
(0.019)\end{array}$ \\
\hline $\mathrm{T}=4$ & $\begin{array}{l}-0.005 \\
(0.033)\end{array}$ & $\begin{array}{c}-0.031^{* * *} \\
(0.011)\end{array}$ & $\begin{array}{c}-0.026 \\
(0.035)\end{array}$ & $\begin{array}{l}-0.003 \\
(0.013)\end{array}$ & $\begin{array}{l}-0.028 \\
(0.030)\end{array}$ & $\begin{array}{l}-0.001 \\
(0.012)\end{array}$ & $\begin{array}{c}-0.033 \\
(0.030)\end{array}$ & $\begin{array}{l}-0.002 \\
(0.013)\end{array}$ \\
\hline $\mathrm{T}=5$ & $\begin{array}{c}0.028 \\
(0.028)\end{array}$ & $\begin{array}{c}0.008 \\
(0.011)\end{array}$ & $\begin{array}{c}0.001 \\
(0.027)\end{array}$ & $\begin{array}{c}0.001 \\
(0.013)\end{array}$ & $\begin{array}{c}0.012 \\
(0.026)\end{array}$ & $\begin{array}{l}-0.011 \\
(0.012)\end{array}$ & $\begin{array}{c}0.015 \\
(0.027)\end{array}$ & $\begin{array}{l}-0.010 \\
(0.014)\end{array}$ \\
\hline $\mathrm{T}>=5$ & $\begin{array}{l}-0.010 \\
(0.014) \\
\end{array}$ & $\begin{array}{c}0.010 \\
(0.011) \\
\end{array}$ & $\begin{array}{c}0.013 \\
(0.014) \\
\end{array}$ & $\begin{array}{c}-0.011 \\
(0.012)\end{array}$ & $\begin{array}{c}0.025^{*} \\
(0.011) \\
\end{array}$ & $\begin{array}{c}0.005 \\
(0.014) \\
\end{array}$ & $\begin{array}{c}0.023 \\
(0.015) \\
\end{array}$ & $\begin{array}{c}0.007 \\
(0.014) \\
\end{array}$ \\
\hline Country-Year FE & \multicolumn{2}{|c|}{$\mathrm{NO}$} & \multicolumn{2}{|c|}{ YES } & \multicolumn{2}{|c|}{ YES } & \multicolumn{2}{|c|}{ YES } \\
\hline Country-industry FE & \multicolumn{2}{|c|}{$\mathrm{NO}$} & \multicolumn{2}{|c|}{ NO } & \multicolumn{2}{|c|}{ YES } & \multicolumn{2}{|c|}{ YES } \\
\hline Industry-year FE & \multicolumn{2}{|c|}{ NO } & \multicolumn{2}{|c|}{ NO } & \multicolumn{2}{|c|}{ NO } & \multicolumn{2}{|c|}{ YES } \\
\hline R-squared & \multicolumn{2}{|c|}{0.001} & \multicolumn{2}{|c|}{0.140} & \multicolumn{2}{|c|}{0.242} & \multicolumn{2}{|c|}{0.242} \\
\hline $\mathrm{N}$ & \multicolumn{2}{|c|}{51,299} & \multicolumn{2}{|c|}{51,299} & \multicolumn{2}{|c|}{51,299} & \multicolumn{2}{|c|}{51,299} \\
\hline
\end{tabular}

Notes: The dependent variable is the change in the MFN tariff between years $\mathrm{t}$ and (t-1). ${ }^{*}$ significant at $10 \%,{ }^{* *}$ significant at $5 \%$, $* * *$ significant at $1 \%$. Standard errors in parentheses are clustered at the country-industry level. Observations with more than $10 \%$ changes in MFN tariff are excluded from the analysis. In columns (a) and (b) the explanatory variables are constructed over positive and negative changes in preferential export shares, respectively. All specifications include tariff reciprocity variables as additional controls. 
Table 4. IV results

(1)

(2)

(3)

(4)

(5)

(6)

IV-GMM IV-GMM IV-GMM IV-GMM IV-GMM IV-GMM

Instrumented:

import shares

import shares and pref. import shares and pref.

export shares

export shares

\begin{tabular}{|c|c|c|c|c|c|c|}
\hline $\operatorname{PXS}(\mathrm{T}=1)$ & $\begin{array}{c}-0.030 \\
(0.079)\end{array}$ & $\begin{array}{c}-0.041 \\
(0.085)\end{array}$ & $\begin{array}{c}0.109 \\
(0.204)\end{array}$ & $\begin{array}{c}0.003 \\
(0.187)\end{array}$ & $\begin{array}{c}0.097 \\
(0.182)\end{array}$ & $\begin{array}{c}-0.025 \\
(0.157)\end{array}$ \\
\hline $\operatorname{PXS}(\mathrm{T}=2)$ & $\begin{array}{c}-0.114^{* *} \\
(0.047)\end{array}$ & $\begin{array}{c}-0.110^{* *} \\
(0.046)\end{array}$ & $\begin{array}{c}-0.487^{* *} \\
(0.206)\end{array}$ & $\begin{array}{c}-0.545^{* *} \\
(0.215)\end{array}$ & $\begin{array}{c}-0.355^{* *} \\
(0.164)\end{array}$ & $\begin{array}{c}-0.346^{* *} \\
(0.160)\end{array}$ \\
\hline $\operatorname{PXS}(\mathrm{T}=3)$ & $\begin{array}{c}-0.154^{* *} \\
(0.067)\end{array}$ & $\begin{array}{c}-0.151^{* * *} \\
(0.055)\end{array}$ & $\begin{array}{c}-0.334^{*} \\
(0.173)\end{array}$ & $\begin{array}{c}-0.467^{* *} \\
(0.198)\end{array}$ & $\begin{array}{l}-0.331^{*} \\
(0.173)\end{array}$ & $\begin{array}{c}-0.451^{* * *} \\
(0.175)\end{array}$ \\
\hline $\operatorname{PXS}(\mathrm{T}=4)$ & $\begin{array}{c}-0.064 \\
(0.055)\end{array}$ & $\begin{array}{c}-0.040 \\
(0.053)\end{array}$ & $\begin{array}{c}0.028 \\
(0.100)\end{array}$ & $\begin{array}{c}-0.079 \\
(0.100)\end{array}$ & $\begin{array}{c}0.042 \\
(0.096)\end{array}$ & $\begin{array}{c}-0.070 \\
(0.095)\end{array}$ \\
\hline $\operatorname{PXS}(\mathrm{T}=5)$ & $\begin{array}{c}-0.104^{* * *} \\
(0.035)\end{array}$ & $\begin{array}{c}-0.098^{* * *} \\
(0.035)\end{array}$ & $\begin{array}{c}0.047 \\
(0.079)\end{array}$ & $\begin{array}{c}0.055 \\
(0.064)\end{array}$ & $\begin{array}{c}0.037 \\
(0.079)\end{array}$ & $\begin{array}{c}0.032 \\
(0.072)\end{array}$ \\
\hline $\mathrm{PXS}(\mathrm{T}>5)$ & $\begin{array}{c}-0.004 \\
(0.018)\end{array}$ & $\begin{array}{c}-0.004 \\
(0.019)\end{array}$ & $\begin{array}{c}-0.047 \\
(0.057)\end{array}$ & $\begin{array}{c}0.003 \\
(0.074)\end{array}$ & $\begin{array}{c}-0.057 \\
(0.052)\end{array}$ & $\begin{array}{c}-0.011 \\
(0.069)\end{array}$ \\
\hline Country-Year FE & YES & YES & YES & YES & YES & YES \\
\hline Country-industry FE & NO & YES & NO & YES & NO & YES \\
\hline $\mathrm{N}$ & 51,287 & 51,287 & 51,287 & 51,287 & 51,287 & 51,287 \\
\hline Instrument set & IV1 & IV1 & IV2 & IV2 & IV2 \& IV3 & IV2 \& IV3 \\
\hline Hansen J test, p-value & & & & & 0.727 & 0.277 \\
\hline \multicolumn{7}{|l|}{ AP p-val: } \\
\hline $\operatorname{PXS}(\mathrm{T}=1)$ & 0.000 & 0.000 & 0.002 & 0.001 & 0.004 & 0.001 \\
\hline $\operatorname{PXS}(\mathrm{T}=2)$ & 0.000 & 0.000 & 0.001 & 0.001 & 0.000 & 0.000 \\
\hline $\operatorname{PXS}(\mathrm{T}=3)$ & 0.000 & 0.000 & 0.000 & 0.000 & 0.000 & 0.000 \\
\hline $\operatorname{PXS}(\mathrm{T}=4)$ & 0.000 & 0.000 & 0.000 & 0.000 & 0.000 & 0.000 \\
\hline $\operatorname{PXS}(\mathrm{T}=5)$ & 0.000 & 0.000 & 0.000 & 0.000 & 0.000 & 0.000 \\
\hline $\operatorname{PXS}(\mathrm{T}>5)$ & 0.000 & 0.000 & 0.000 & 0.000 & 0.000 & 0.000 \\
\hline \multicolumn{7}{|l|}{ F-stat: } \\
\hline $\mathrm{PXS}(\mathrm{T}=1)$ & 6.81 & 8.63 & 3.43 & 3.58 & 2.51 & 2.33 \\
\hline $\operatorname{PXS}(\mathrm{T}=2)$ & 7.04 & 9.84 & 3.61 & 3.98 & 3.76 & 4.18 \\
\hline $\mathrm{PXS}(\mathrm{T}=3)$ & 7.84 & 7.46 & 6.45 & 6.13 & 4.99 & 4.38 \\
\hline $\mathrm{PXS}(\mathrm{T}=4)$ & 15.55 & 17.37 & 14.17 & 14.5 & 5.34 & 5.56 \\
\hline $\mathrm{PXS}(\mathrm{T}=5)$ & 17.4 & 18.58 & 11.77 & 13.34 & 7.19 & 7.26 \\
\hline $\mathrm{PXS}(\mathrm{T}>5)$ & 31.25 & 32.79 & 10.68 & 8.50 & 14.41 & 10.26 \\
\hline
\end{tabular}

Notes: The dependent variable is the change in the MFN tariff between years $\mathrm{t}$ and $(\mathrm{t}-1) .{ }^{*}$ significant at $10 \%,{ }^{* *}$ significant at $5 \%, * * *$ significant at $1 \%$. Observations with more than $10 \%$ changes in MFN tariff are excluded from the analysis. Standard errors in parentheses are clustered at the country-industry level. Columns (1)-(4) use as instruments PPX(T) where import shares are predicted from the gravity model. Columns (5)-(8) use as instruments PPX(T) where import shares are predicted from the gravity model and preferential export shares are predicted from the preference margin equation. AP reports the p-value of the Angrist-Pischke test for the strength of the instruments in the first stage regressions. 
Table 5. Results with political economy

\begin{tabular}{|c|c|c|c|c|c|c|c|c|c|c|c|c|}
\hline & \multicolumn{2}{|c|}{ (1) } & \multicolumn{2}{|c|}{ (2) } & \multicolumn{2}{|c|}{ (3) } & \multicolumn{2}{|c|}{ (4) } & \multicolumn{4}{|c|}{ (5) } \\
\hline & (a) & (b) & (a) & (b) & (a) & (b) & (a) & (b) & (a) & (b) & (c) & (d) \\
\hline & PXS(T) & $\mathrm{PXS}(\mathrm{T}) \times a$ & PXS(T) & $\mathrm{XS}(\mathrm{T}) \times \mathrm{I}_{25}$ & PXS(T) & $\operatorname{PXS}(\mathrm{T}) \times \mathrm{I}_{50}$ & $\operatorname{PXS}(\mathrm{T})$ & $\mathrm{PXS}(\mathrm{T}) \times \mathrm{I}_{75}$ & $\operatorname{PXS}(\mathrm{T})$ & $\operatorname{PXS}(\mathrm{T}) \times \mathrm{D}_{2}$ & $\mathrm{PXS}(\mathrm{T}) \times \mathrm{D}_{3}$ & $\mathrm{PXS}(\mathrm{T}) \times \mathrm{D}_{4}$ \\
\hline $\mathrm{T}=1$ & $\begin{array}{c}-0.017 \\
(0.024)\end{array}$ & $\begin{array}{c}-0.002 \\
(0.003)\end{array}$ & $\begin{array}{c}-0.033 \\
(0.022)\end{array}$ & $\begin{array}{c}-0.013 \\
(0.038)\end{array}$ & $\begin{array}{c}-0.032 \\
(0.020)\end{array}$ & $\begin{array}{c}-0.029 \\
(0.046)\end{array}$ & $\begin{array}{l}-0.039^{* *} \\
(0.018)\end{array}$ & $\begin{array}{c}0.021 \\
(0.093)\end{array}$ & $\begin{array}{l}-0.033 \\
(0.022)\end{array}$ & $\begin{array}{c}0.015 \\
(0.047)\end{array}$ & $\begin{array}{c}-0.058 \\
(0.049)\end{array}$ & $\begin{array}{c}0.015 \\
(0.094)\end{array}$ \\
\hline $\mathrm{T}=2$ & $\begin{array}{c}-0.046^{*} \\
(0.024)\end{array}$ & $\begin{array}{c}0.001 \\
(0.003)\end{array}$ & $\begin{array}{c}-0.051^{* * *} \\
(0.017)\end{array}$ & $\begin{array}{c}0.016 \\
(0.029)\end{array}$ & $\begin{array}{c}-0.046^{* * *} \\
(0.016)\end{array}$ & $\begin{array}{c}-0.008 \\
(0.033)\end{array}$ & $\begin{array}{l}-0.047^{* *} \\
(0.015)\end{array}$ & $\begin{array}{c}-0.009 \\
(0.078)\end{array}$ & $\begin{array}{l}-0.051^{* * *} \\
(0.017)\end{array}$ & $\begin{array}{c}0.047 \\
(0.045)\end{array}$ & $\begin{array}{c}-0.007 \\
(0.031)\end{array}$ & $\begin{array}{l}-0.005 \\
(0.078)\end{array}$ \\
\hline $\mathrm{T}=3$ & $\begin{array}{c}-0.048^{*} \\
(0.027)\end{array}$ & $\begin{array}{c}0.005^{*} \\
(0.003)\end{array}$ & $\begin{array}{l}-0.029^{*} \\
(0.016)\end{array}$ & $\begin{array}{c}-0.000 \\
(0.026)\end{array}$ & $\begin{array}{l}-0.030^{* *} \\
(0.015)\end{array}$ & $\begin{array}{c}0.002 \\
(0.027)\end{array}$ & $\begin{array}{l}-0.032^{* *} \\
(0.014)\end{array}$ & $\begin{array}{c}0.118^{*} \\
(0.072)\end{array}$ & $\begin{array}{c}-0.029^{*} \\
(0.016)\end{array}$ & $\begin{array}{c}-0.002 \\
(0.041)\end{array}$ & $\begin{array}{c}-0.026 \\
(0.029)\end{array}$ & $\begin{array}{c}0.115 \\
(0.072)\end{array}$ \\
\hline $\mathrm{T}=4$ & $\begin{array}{c}0.027 \\
(0.028)\end{array}$ & $\begin{array}{c}-0.001 \\
(0.003)\end{array}$ & $\begin{array}{c}-0.025 \\
(0.016)\end{array}$ & $\begin{array}{c}0.047 \\
(0.033)\end{array}$ & $\begin{array}{c}-0.017 \\
(0.016)\end{array}$ & $\begin{array}{c}0.032 \\
(0.029)\end{array}$ & $\begin{array}{c}-0.014 \\
(0.014)\end{array}$ & $\begin{array}{c}0.000 \\
(0.085)\end{array}$ & $\begin{array}{l}-0.025 \\
(0.016)\end{array}$ & $\begin{array}{c}0.065 \\
(0.059)\end{array}$ & $\begin{array}{c}0.038 \\
(0.029)\end{array}$ & $\begin{array}{c}0.011 \\
(0.085)\end{array}$ \\
\hline $\mathrm{T}=5$ & $\begin{array}{c}0.040 \\
(0.028)\end{array}$ & $\begin{array}{c}0.002 \\
(0.003)\end{array}$ & $\begin{array}{c}-0.018 \\
(0.017)\end{array}$ & $\begin{array}{c}0.032 \\
(0.030)\end{array}$ & $\begin{array}{c}-0.021 \\
(0.016)\end{array}$ & $\begin{array}{c}0.079 * * * \\
(0.030)\end{array}$ & $\begin{array}{l}-0.016 \\
(0.015)\end{array}$ & $\begin{array}{c}0.145^{*} \\
(0.078)\end{array}$ & $\begin{array}{l}-0.018 \\
(0.017)\end{array}$ & $\begin{array}{c}-0.055 \\
(0.059)\end{array}$ & $\begin{array}{c}0.054^{*} \\
(0.032)\end{array}$ & $\begin{array}{c}0.148^{*} \\
(0.078)\end{array}$ \\
\hline $\mathrm{T}>5$ & $\begin{array}{c}0.028 \\
(0.020)\end{array}$ & $\begin{array}{c}-0.006 \\
(0.004)\end{array}$ & $\begin{array}{c}0.014 \\
(0.012)\end{array}$ & $\begin{array}{c}-0.009 \\
(0.019)\end{array}$ & $\begin{array}{c}0.013 \\
(0.010)\end{array}$ & $\begin{array}{c}-0.030 \\
(0.022)\end{array}$ & $\begin{array}{c}0.013 \\
(0.009)\end{array}$ & $\begin{array}{c}-0.156 \\
(0.109)\end{array}$ & $\begin{array}{c}0.014 \\
(0.012)\end{array}$ & $\begin{array}{c}-0.006 \\
(0.022)\end{array}$ & $\begin{array}{c}-0.009 \\
(0.020)\end{array}$ & $\begin{array}{l}-0.157 \\
(0.110)\end{array}$ \\
\hline $\mathrm{R} 2$ & \multicolumn{2}{|c|}{0.122} & \multicolumn{2}{|c|}{0.106} & \multicolumn{2}{|c|}{0.106} & \multicolumn{2}{|c|}{0.106} & \multicolumn{4}{|c|}{0.106} \\
\hline $\mathrm{N}$ & \multicolumn{2}{|c|}{22,876} & \multicolumn{2}{|c|}{51,229} & \multicolumn{2}{|c|}{51,229} & \multicolumn{2}{|c|}{51,229} & \multicolumn{4}{|c|}{51,229} \\
\hline
\end{tabular}


Table 6. Benchmark results with 3- and 4-digit HS product data

\begin{tabular}{|c|c|c|c|c|c|c|c|c|}
\hline & \multicolumn{4}{|c|}{ HS3 } & \multirow[b]{2}{*}{ (5) } & \multicolumn{2}{|c|}{ HS4 } & \multirow[b]{2}{*}{ (8) } \\
\hline & (1) & $(2)$ & (3) & (4) & & (6) & (7) & \\
\hline $\operatorname{PPX}(\mathrm{T}=1)$ & $\begin{array}{c}-0.049^{* * *} \\
(0.012)\end{array}$ & $\begin{array}{c}-0.027^{* *} \\
(0.012)\end{array}$ & $\begin{array}{c}-0.014 \\
(0.011)\end{array}$ & $\begin{array}{c}-0.017 \\
(0.011)\end{array}$ & $\begin{array}{c}-0.007^{* * *} \\
(0.002)\end{array}$ & $\begin{array}{c}-0.002 \\
(0.002)\end{array}$ & $\begin{array}{c}-0.002 \\
(0.002)\end{array}$ & $\begin{array}{c}-0.002 \\
(0.002)\end{array}$ \\
\hline $\operatorname{PPX}(\mathrm{T}=2)$ & $\begin{array}{c}-0.013 \\
(0.009)\end{array}$ & $\begin{array}{c}-0.023^{* * *} \\
(0.009)\end{array}$ & $\begin{array}{c}-0.017^{*} \\
(0.009)\end{array}$ & $\begin{array}{l}-0.015^{*} \\
(0.009)\end{array}$ & $\begin{array}{c}0.001 \\
(0.002)\end{array}$ & $\begin{array}{c}-0.005^{* * *} \\
(0.002)\end{array}$ & $\begin{array}{c}-0.005^{* * *} \\
(0.002)\end{array}$ & $\begin{array}{c}-0.005^{* * *} \\
(0.002)\end{array}$ \\
\hline $\operatorname{PPX}(\mathrm{T}=3)$ & $\begin{array}{c}-0.039^{* * *} \\
(0.010)\end{array}$ & $\begin{array}{c}-0.028^{* * *} \\
(0.009)\end{array}$ & $\begin{array}{c}-0.023^{* * *} \\
(0.008)\end{array}$ & $\begin{array}{c}-0.023^{* * *} \\
(0.008)\end{array}$ & $\begin{array}{c}-0.010^{* * *} \\
(0.002)\end{array}$ & $\begin{array}{c}-0.005^{* * *} \\
(0.002)\end{array}$ & $\begin{array}{c}-0.005^{* * *} \\
(0.002)\end{array}$ & $\begin{array}{c}-0.004^{* *} \\
(0.002)\end{array}$ \\
\hline $\mathrm{PPX}(\mathrm{T}=4)$ & $\begin{array}{c}-0.026^{* * *} \\
(0.010)\end{array}$ & $\begin{array}{c}-0.026^{* * *} \\
(0.009)\end{array}$ & $\begin{array}{c}-0.015 \\
(0.009)\end{array}$ & $\begin{array}{c}-0.017^{*} \\
(0.009)\end{array}$ & $\begin{array}{c}-0.003 \\
(0.002)\end{array}$ & $\begin{array}{c}-0.002 \\
(0.002)\end{array}$ & $\begin{array}{c}-0.002 \\
(0.002)\end{array}$ & $\begin{array}{c}-0.001 \\
(0.002)\end{array}$ \\
\hline $\operatorname{PPX}(\mathrm{T}=5)$ & $\begin{array}{c}-0.002 \\
(0.010)\end{array}$ & $\begin{array}{c}-0.021^{* *} \\
(0.009)\end{array}$ & $\begin{array}{l}-0.016^{*} \\
(0.009)\end{array}$ & $\begin{array}{l}-0.016^{*} \\
(0.009)\end{array}$ & $\begin{array}{l}-0.003^{*} \\
(0.002)\end{array}$ & $\begin{array}{l}-0.003^{*} \\
(0.002)\end{array}$ & $\begin{array}{l}-0.003^{*} \\
(0.002)\end{array}$ & $\begin{array}{c}-0.002 \\
(0.002)\end{array}$ \\
\hline $\operatorname{PPX}(T>5)$ & $\begin{array}{c}0.009 \\
(0.006)\end{array}$ & $\begin{array}{c}-0.008 \\
(0.006)\end{array}$ & $\begin{array}{c}-0.003 \\
(0.007)\end{array}$ & $\begin{array}{c}-0.003 \\
(0.007)\end{array}$ & $\begin{array}{c}0.008^{* * *} \\
(0.001)\end{array}$ & $\begin{array}{c}0.002 \\
(0.001)\end{array}$ & $\begin{array}{c}0.002 \\
(0.001)\end{array}$ & $\begin{array}{c}0.001 \\
(0.001)\end{array}$ \\
\hline Constant & $\begin{array}{c}-0.005^{* * *} \\
(0.000)\end{array}$ & $\begin{array}{c}-0.005^{* * *} \\
(0.000)\end{array}$ & $\begin{array}{c}-0.004^{* * *} \\
(0.000)\end{array}$ & $\begin{array}{c}-0.004^{* * *} \\
(0.000)\end{array}$ & $\begin{array}{c}-0.003^{* * *} \\
(0.000)\end{array}$ & $\begin{array}{c}-0.003^{* * *} \\
(0.000)\end{array}$ & $\begin{array}{c}-0.002^{* * *} \\
(0.000)\end{array}$ & $\begin{array}{c}-0.002^{* * *} \\
(0.000)\end{array}$ \\
\hline Country-Year FE & NO & YES & YES & YES & NO & YES & YES & YES \\
\hline Country-industry FE & NO & NO & YES & YES & NO & NO & YES & YES \\
\hline Industry-year FE & NO & NO & NO & YES & NO & NO & NO & YES \\
\hline Control for reciprocity & NO & NO & NO & YES & NO & NO & NO & YES \\
\hline R-squared & 0.001 & 0.131 & 0.109 & 0.109 & 0.000 & 0.226 & 0.226 & 0.234 \\
\hline $\mathrm{N}$ & 85,369 & 85,369 & 85,369 & 85,369 & 478,517 & 478,517 & 478,517 & 478,517 \\
\hline
\end{tabular}


Table 7. IV results with 4-digit HS product data

\begin{tabular}{|c|c|c|c|c|c|c|c|c|}
\hline \multirow[b]{2}{*}{ Instrumented: } & \multicolumn{4}{|c|}{ HS3 } & \multicolumn{4}{|c|}{ HS4 } \\
\hline & $\begin{array}{c}\text { (1) } \\
\text { IV-GMM } \\
\text { import s }\end{array}$ & $\begin{array}{l}\text { (2) } \\
\text { IV-GMM } \\
\text { shares }\end{array}$ & $\begin{array}{c}\text { (3) } \\
\text { IV-GMM } \\
\text { import } \\
\text { and pref. } \\
\text { shar }\end{array}$ & $\begin{array}{l}\text { (4) } \\
\text { IV- } \\
\text { GMM } \\
\text { shares } \\
\text { f. export } \\
\text { res }\end{array}$ & $\begin{array}{l}\text { (5) } \\
\text { IV- } \\
\text { GMM } \\
\text { import }\end{array}$ & $\begin{array}{c}(6) \\
\text { IV- } \\
\text { GMM }\end{array}$ & $\begin{array}{l}\text { (7) } \\
\text { IV- } \\
\text { GMM } \\
\text { import s } \\
\text { and pref. } \\
\text { shar } \\
\end{array}$ & $\begin{array}{l}\text { (8) } \\
\text { IV- } \\
\text { GMM } \\
\text { shares } \\
\text { f. export } \\
\text { res } \\
\end{array}$ \\
\hline $\operatorname{PPX}(\mathrm{T}=1)$ & $\begin{array}{c}-0.025 \\
(0.017)\end{array}$ & $\begin{array}{c}-0.020 \\
(0.019)\end{array}$ & $\begin{array}{c}-0.204 \\
(0.145)\end{array}$ & $\begin{array}{c}-0.025 \\
(0.163)\end{array}$ & $\begin{array}{c}-0.009 \\
(0.006)\end{array}$ & $\begin{array}{c}-0.008 \\
(0.006)\end{array}$ & $\begin{array}{c}-0.016 \\
(0.015)\end{array}$ & $\begin{array}{c}-0.014 \\
(0.015)\end{array}$ \\
\hline $\operatorname{PPX}(\mathrm{T}=2)$ & $\begin{array}{l}-0.057^{* * *} \\
(0.017)\end{array}$ & $\begin{array}{c}-0.045^{* *} \\
(0.019)\end{array}$ & $\begin{array}{l}-0.314^{*} \\
(0.164)\end{array}$ & $\begin{array}{l}-0.324^{*} \\
(0.167)\end{array}$ & $\begin{array}{c}-0.024^{* * *} \\
(0.005)\end{array}$ & $\begin{array}{c}-0.021^{* * *} \\
(0.005)\end{array}$ & $\begin{array}{l}-0.024^{* * *} \\
(0.005)\end{array}$ & $\begin{array}{c}-0.052^{* * *} \\
(0.016)\end{array}$ \\
\hline $\operatorname{PPX}(\mathrm{T}=3)$ & $\begin{array}{l}-0.061^{* * *} \\
(0.023)\end{array}$ & $\begin{array}{l}-0.060^{* * *} \\
(0.023)\end{array}$ & $\begin{array}{l}-0.356^{* *} \\
(0.142)\end{array}$ & $\begin{array}{c}-0.442^{* * *} \\
(0.151)\end{array}$ & $\begin{array}{c}-0.012^{* * *} \\
(0.004)\end{array}$ & $\begin{array}{r}-0.010^{* *} \\
(0.005)\end{array}$ & $\begin{array}{c}-0.012^{* * *} \\
(0.004)\end{array}$ & $\begin{array}{c}-0.028^{* * *} \\
(0.009)\end{array}$ \\
\hline $\mathrm{PPX}(\mathrm{T}=4)$ & $\begin{array}{c}-0.029 \\
(0.025)\end{array}$ & $\begin{array}{c}-0.024 \\
(0.024)\end{array}$ & $\begin{array}{c}-0.077 \\
(0.103)\end{array}$ & $\begin{array}{c}-0.095 \\
(0.106)\end{array}$ & $\begin{array}{c}-0.004 \\
(0.004)\end{array}$ & $\begin{array}{c}-0.000 \\
(0.004)\end{array}$ & $\begin{array}{c}-0.004 \\
(0.004)\end{array}$ & $\begin{array}{c}0.004 \\
(0.008)\end{array}$ \\
\hline $\mathrm{PPX}(\mathrm{T}=5)$ & $\begin{array}{c}-0.019 \\
(0.015)\end{array}$ & $\begin{array}{c}-0.027 \\
(0.017)\end{array}$ & $\begin{array}{l}-0.010 \\
(0.037)\end{array}$ & $\begin{array}{c}-0.010 \\
(0.039)\end{array}$ & $\begin{array}{c}0.000 \\
(0.002)\end{array}$ & $\begin{array}{c}-0.000 \\
(0.002)\end{array}$ & $\begin{array}{c}-0.000 \\
(0.002)\end{array}$ & $\begin{array}{c}0.001 \\
(0.006)\end{array}$ \\
\hline $\operatorname{PPX}(\mathrm{T}>5)$ & $\begin{array}{c}-0.042^{* * *} \\
(0.009)\end{array}$ & $\begin{array}{l}-0.032^{* * *} \\
(0.010)\end{array}$ & $\begin{array}{c}-0.014 \\
(0.035)\end{array}$ & $\begin{array}{c}0.048 \\
(0.035)\end{array}$ & $\begin{array}{c}-0.001 \\
(0.002)\end{array}$ & $\begin{array}{c}0.000 \\
(0.002)\end{array}$ & $\begin{array}{c}-0.001 \\
(0.002)\end{array}$ & $\begin{array}{c}0.004 \\
(0.008)\end{array}$ \\
\hline Country-Year FE & YES & YES & YES & YES & YES & YES & YES & YES \\
\hline Country-industry FE & NO & YES & NO & YES & NO & YES & NO & YES \\
\hline $\mathrm{N}$ & 85,360 & 85,360 & 85,360 & 85,360 & 478512 & 478512 & 478512 & 478512 \\
\hline \multicolumn{9}{|l|}{ AP p-val: } \\
\hline $\operatorname{PXS}(\mathrm{T}=1)$ & 0.000 & 0.000 & 0.000 & 0.000 & 0.000 & 0.000 & 0.000 & 0.000 \\
\hline $\operatorname{PXS}(\mathrm{T}=2)$ & 0.000 & 0.000 & 0.000 & 0.000 & 0.000 & 0.000 & 0.000 & 0.000 \\
\hline $\mathrm{PXS}(\mathrm{T}=3)$ & 0.000 & 0.000 & 0.000 & 0.000 & 0.000 & 0.000 & 0.000 & 0.000 \\
\hline $\operatorname{PXS}(\mathrm{T}=4)$ & 0.000 & 0.000 & 0.000 & 0.000 & 0.000 & 0.000 & 0.000 & 0.000 \\
\hline $\mathrm{PXS}(\mathrm{T}=5)$ & 0.000 & 0.000 & 0.000 & 0.000 & 0.000 & 0.000 & 0.000 & 0.000 \\
\hline $\mathrm{PXS}(\mathrm{T}>5)$ & 0.000 & 0.000 & 0.000 & 0.000 & 0.000 & 0.000 & 0.000 & 0.000 \\
\hline \multicolumn{9}{|l|}{ F-stat: } \\
\hline $\operatorname{PXS}(\mathrm{T}=1)$ & 24.6 & 32.5 & 12.9 & 13.6 & 65.16 & 109.61 & 5.94 & 10.49 \\
\hline $\operatorname{PXS}(\mathrm{T}=2)$ & 27.7 & 46.2 & 8.3 & 8.3 & 132.47 & 92.28 & 32.13 & 24.57 \\
\hline $\operatorname{PXS}(\mathrm{T}=3)$ & 13.3 & 22.9 & 7.8 & 8.4 & 76.96 & 47.02 & 75.12 & 13.13 \\
\hline $\mathrm{PXS}(\mathrm{T}=4)$ & 31.6 & 51.7 & 9.3 & 8.9 & 92.31 & 99.23 & 92.16 & 41.72 \\
\hline $\mathrm{PXS}(\mathrm{T}=5)$ & 31.7 & 32.5 & 11.9 & 12.4 & 218.69 & 57.41 & 218.30 & 40.37 \\
\hline $\mathrm{PXS}(\mathrm{T}>5)$ & 36.3 & 62.3 & 23.4 & 20.3 & 158.6 & 142.2 & 178.3 & 20.8 \\
\hline $\begin{array}{l}\text { Notes: The dependen } \\
\text { significant at } 5 \%,{ }^{* *} \\
\text { Observations with m } \\
\text { instruments PPX(T) } \\
\text { PPX(T) where import }\end{array}$ & $\begin{array}{l}\text { is the } \\
\text { it at } 1 \% \\
10 \% \text { ch } \\
\text { ort shar } \\
\text { e predic }\end{array}$ & $\begin{array}{l}\text { ge in } \\
\text { ndard } \\
s \text { in } N \\
\text { re pre } \\
\text { rom } t\end{array}$ & $\begin{array}{l}\text { MFN ta } \\
\text { ors in } p \\
\text { tariff a } \\
\text { d from } \\
\text { avity } n\end{array}$ & $\begin{array}{l}\text { iff betwee } \\
\text { rentheses } \\
\text { exclude } \\
\text { he gravit } \\
\text { odel and }\end{array}$ & $\begin{array}{l}\text { ears } t \text { an } \\
\text { e clustere } \\
\text { om the ar } \\
\text { odel. Colu } \\
\text { erential ex }\end{array}$ & $\begin{array}{l}\mathrm{d}(\mathrm{t}-1) \cdot{ }^{*} \mathrm{si} \\
\mathrm{d} \text { at the co } \\
\text { nalysis. Col } \\
\text { imns (5)-(8 } \\
\text { xport share }\end{array}$ & $\begin{array}{l}\text { nificant } \\
\text { ntry-ind } \\
\text { mns (1)- } \\
\text { use as in } \\
\text { are pred }\end{array}$ & $\begin{array}{l}10 \%, * * \\
\text { try level. } \\
\text { t) use as } \\
\text { truments } \\
\text { ted from }\end{array}$ \\
\hline
\end{tabular}


Table 8. Results with trade diversion

\begin{tabular}{|c|c|c|c|c|c|c|}
\hline \multirow[b]{3}{*}{ Instrumented: } & (1) & (2) & (3) & $(4)$ & (5) & (6) \\
\hline & OLS & OLS & IV-GMM & IV-GMM & IV-GMM & IV-GMM \\
\hline & & & \multicolumn{2}{|c|}{ import shares } & \multicolumn{2}{|c|}{$\begin{array}{l}\text { import shares and } \\
\text { pref. export shares }\end{array}$} \\
\hline $\operatorname{PXS}(\mathrm{T}=1)$ & $\begin{array}{c}-0.056^{* * *} \\
(0.018)\end{array}$ & $\begin{array}{l}-0.039^{* *} \\
(0.018)\end{array}$ & $\begin{array}{l}-0.030 \\
(0.079)\end{array}$ & $\begin{array}{l}-0.034 \\
(0.084)\end{array}$ & $\begin{array}{c}0.126 \\
(0.206)\end{array}$ & $\begin{array}{c}0.024 \\
(0.187)\end{array}$ \\
\hline $\operatorname{PXS}(\mathrm{T}=2)$ & $\begin{array}{c}-0.043^{* * *} \\
(0.014)\end{array}$ & $\begin{array}{c}-0.049^{* * *} \\
(0.014)\end{array}$ & $\begin{array}{c}-0.119^{* *} \\
(0.047)\end{array}$ & $\begin{array}{c}-0.113^{* *} \\
(0.046)\end{array}$ & $\begin{array}{c}-0.487^{* *} \\
(0.204)\end{array}$ & $\begin{array}{c}-0.538^{* *} \\
(0.213)\end{array}$ \\
\hline $\operatorname{PXS}(\mathrm{T}=3)$ & $\begin{array}{c}-0.039 * * * \\
(0.014)\end{array}$ & $\begin{array}{c}-0.031^{* *} \\
(0.013)\end{array}$ & $\begin{array}{l}-0.158^{* *} \\
(0.067)\end{array}$ & $\begin{array}{c}-0.156^{* * *} \\
(0.054)\end{array}$ & $\begin{array}{c}-0.345^{* *} \\
(0.174)\end{array}$ & $\begin{array}{c}-0.481^{* *} \\
(0.202)\end{array}$ \\
\hline $\operatorname{PXS}(\mathrm{T}=4)$ & $\begin{array}{c}-0.034^{* *} \\
(0.015)\end{array}$ & $\begin{array}{c}-0.015 \\
(0.014)\end{array}$ & $\begin{array}{c}-0.070 \\
(0.054)\end{array}$ & $\begin{array}{c}-0.042 \\
(0.053)\end{array}$ & $\begin{array}{c}0.024 \\
(0.099)\end{array}$ & $\begin{array}{c}-0.077 \\
(0.099)\end{array}$ \\
\hline $\operatorname{PXS}(\mathrm{T}=5)$ & $\begin{array}{l}-0.011 \\
(0.015)\end{array}$ & $\begin{array}{l}-0.014 \\
(0.015)\end{array}$ & $\begin{array}{c}-0.107^{* * *} \\
(0.034)\end{array}$ & $\begin{array}{c}-0.101^{* * *} \\
(0.035)\end{array}$ & $\begin{array}{c}0.048 \\
(0.078)\end{array}$ & $\begin{array}{c}0.063 \\
(0.064)\end{array}$ \\
\hline $\operatorname{PXS}(\mathrm{T}>5)$ & $\begin{array}{c}0.004 \\
(0.008) \\
\end{array}$ & $\begin{array}{c}0.011 \\
(0.009) \\
\end{array}$ & $\begin{array}{c}-0.004 \\
(0.018) \\
\end{array}$ & $\begin{array}{c}-0.004 \\
(0.019) \\
\end{array}$ & $\begin{array}{c}-0.054 \\
(0.057) \\
\end{array}$ & $\begin{array}{c}-0.006 \\
(0.074) \\
\end{array}$ \\
\hline $\mathrm{TD}(\mathrm{T}=1)$ & $\begin{array}{l}-0.002 \\
(0.004)\end{array}$ & $\begin{array}{l}-0.004 \\
(0.004)\end{array}$ & $\begin{array}{l}-0.003 \\
(0.010)\end{array}$ & $\begin{array}{l}-0.016^{*} \\
(0.009)\end{array}$ & $\begin{array}{l}-0.008 \\
(0.010)\end{array}$ & $\begin{array}{c}-0.021^{* *} \\
(0.010)\end{array}$ \\
\hline $\mathrm{TD}(\mathrm{T}=2)$ & $\begin{array}{c}-0.003 \\
(0.004)\end{array}$ & $\begin{array}{c}-0.005 \\
(0.004)\end{array}$ & $\begin{array}{c}-0.008 \\
(0.009)\end{array}$ & $\begin{array}{c}-0.009 \\
(0.008)\end{array}$ & $\begin{array}{c}-0.010 \\
(0.010)\end{array}$ & $\begin{array}{l}-0.012 \\
(0.009)\end{array}$ \\
\hline $\mathrm{TD}(\mathrm{T}=3)$ & $\begin{array}{c}0.001 \\
(0.004)\end{array}$ & $\begin{array}{c}0.002 \\
(0.003)\end{array}$ & $\begin{array}{c}0.003 \\
(0.009)\end{array}$ & $\begin{array}{c}0.003 \\
(0.008)\end{array}$ & $\begin{array}{c}0.007 \\
(0.009)\end{array}$ & $\begin{array}{c}0.006 \\
(0.009)\end{array}$ \\
\hline $\mathrm{TD}(\mathrm{T}=4)$ & $\begin{array}{c}-0.003 \\
(0.003)\end{array}$ & $\begin{array}{c}-0.003 \\
(0.003)\end{array}$ & $\begin{array}{c}-0.019 * * \\
(0.008)\end{array}$ & $\begin{array}{c}-0.019 * * \\
(0.008)\end{array}$ & $\begin{array}{c}-0.019 * * \\
(0.008)\end{array}$ & $\begin{array}{c}-0.019 * * \\
(0.008)\end{array}$ \\
\hline $\mathrm{TD}(\mathrm{T}=5)$ & $\begin{array}{c}0.004 \\
(0.004)\end{array}$ & $\begin{array}{c}0.007 \\
(0.005)\end{array}$ & $\begin{array}{c}0.001 \\
(0.011)\end{array}$ & $\begin{array}{c}0.011 \\
(0.010)\end{array}$ & $\begin{array}{c}0.002 \\
(0.011)\end{array}$ & $\begin{array}{c}0.011 \\
(0.010)\end{array}$ \\
\hline $\mathrm{TD}(\mathrm{T}>5)$ & $\begin{array}{c}-0.003 \\
(0.005) \\
\end{array}$ & $\begin{array}{l}-0.010^{*} \\
(0.006) \\
\end{array}$ & $\begin{array}{l}-0.024^{*} \\
(0.014) \\
\end{array}$ & $\begin{array}{l}-0.033^{* *} \\
(0.013)\end{array}$ & $\begin{array}{l}-0.024^{*} \\
(0.014) \\
\end{array}$ & $\begin{array}{l}-0.031^{* *} \\
(0.014)\end{array}$ \\
\hline Country-Year FE & YES & YES & YES & YES & YES & YES \\
\hline Country-industry FE & NO & YES & NO & YES & NO & YES \\
\hline R-squared & 0.141 & 0.242 & & & & \\
\hline $\mathrm{N}$ & 52,438 & 52,438 & 52,426 & 52,426 & 52,426 & 52,426 \\
\hline
\end{tabular}


Table 9. Robustness tests

\begin{tabular}{|c|c|c|c|c|c|c|c|c|c|c|c|c|}
\hline & $\begin{array}{l}\text { (1) } \\
\text { OLS }\end{array}$ & $\begin{array}{c}(2) \\
\text { GMM-IV1 }\end{array}$ & $\begin{array}{l}(3) \\
\text { OLS }\end{array}$ & $\begin{array}{l}(4) \\
\text { OLS }\end{array}$ & $\begin{array}{c}\text { (5) } \\
\text { GMM-IV1 }\end{array}$ & $\begin{array}{c}\text { (6) } \\
\text { GMM-IV1 }\end{array}$ & $\begin{array}{l}\text { (7) } \\
\text { OLS }\end{array}$ & $\begin{array}{c}\text { (8) } \\
\text { GMM-IV1 }\end{array}$ & $\begin{array}{l}\text { (9) } \\
\text { OLS }\end{array}$ & $\begin{array}{c}\text { (10) } \\
\text { GMM-IV1 }\end{array}$ & $\begin{array}{l}(9) \\
\text { OLS }\end{array}$ & $\begin{array}{c}\text { (10) } \\
\text { GMM-IV1 }\end{array}$ \\
\hline $\operatorname{PXS}(\mathrm{T}=1)$ & $\begin{array}{c}-0.055^{* * *} \\
(0.019)\end{array}$ & $\begin{array}{l}-0.039 \\
(0.078)\end{array}$ & $\begin{array}{c}-0.060^{* * *} \\
(0.019)\end{array}$ & $\begin{array}{c}-0.013 \\
(0.045)\end{array}$ & $\begin{array}{l}-0.082 \\
(0.109)\end{array}$ & $\begin{array}{c}0.061 \\
(0.059)\end{array}$ & $\begin{array}{l}-0.039^{*} \\
(0.022)\end{array}$ & $\begin{array}{l}-0.035 \\
(0.031)\end{array}$ & $\begin{array}{c}-0.123 \\
(0.122)\end{array}$ & $\begin{array}{c}0.076 \\
(0.097)\end{array}$ & $\begin{array}{c}-0.038^{* *} \\
(0.018)\end{array}$ & $\begin{array}{c}-0.042 \\
(0.085)\end{array}$ \\
\hline $\operatorname{PXS}(\mathrm{T}=2)$ & $\begin{array}{c}-0.028^{* *} \\
(0.011)\end{array}$ & $\begin{array}{c}-0.087^{* *} \\
(0.041)\end{array}$ & $\begin{array}{c}-0.037^{* *} \\
(0.014)\end{array}$ & $\begin{array}{c}-0.197^{* *} \\
(0.100)\end{array}$ & $\begin{array}{c}-0.098^{* *} \\
(0.044)\end{array}$ & $\begin{array}{c}-0.818^{* *} \\
(0.393)\end{array}$ & $\begin{array}{c}-0.051^{* * *} \\
(0.017)\end{array}$ & $\begin{array}{l}-0.044^{*} \\
(0.025)\end{array}$ & $\begin{array}{c}-0.089 \\
(0.060)\end{array}$ & $\begin{array}{c}-0.133^{* *} \\
(0.062)\end{array}$ & $\begin{array}{c}-0.048^{* * *} \\
(0.014)\end{array}$ & $\begin{array}{c}-0.110^{* *} \\
(0.046)\end{array}$ \\
\hline $\operatorname{PXS}(\mathrm{T}=3)$ & $\begin{array}{c}-0.017 \\
(0.015)\end{array}$ & $\begin{array}{c}-0.103^{* *} \\
(0.048)\end{array}$ & $\begin{array}{c}-0.042^{* * *} \\
(0.014)\end{array}$ & $\begin{array}{c}-0.050 \\
(0.077)\end{array}$ & $\begin{array}{c}-0.149^{* * *} \\
(0.056)\end{array}$ & $\begin{array}{l}-0.229 \\
(0.334)\end{array}$ & $\begin{array}{l}-0.020 \\
(0.018)\end{array}$ & $\begin{array}{c}-0.037^{*} \\
(0.019)\end{array}$ & $\begin{array}{c}-0.203^{* *} \\
(0.099)\end{array}$ & $\begin{array}{c}-0.114^{* *} \\
(0.054)\end{array}$ & $\begin{array}{c}-0.030^{* *} \\
(0.013)\end{array}$ & $\begin{array}{c}-0.151^{* * *} \\
(0.055)\end{array}$ \\
\hline $\operatorname{PXS}(\mathrm{T}=4)$ & $\begin{array}{c}-0.006 \\
(0.012)\end{array}$ & $\begin{array}{c}-0.062 \\
(0.059)\end{array}$ & $\begin{array}{c}-0.036^{* *} \\
(0.015)\end{array}$ & $\begin{array}{c}0.026 \\
(0.071)\end{array}$ & $\begin{array}{l}-0.046 \\
(0.054)\end{array}$ & $\begin{array}{c}-0.183 \\
(0.383)\end{array}$ & $\begin{array}{c}0.000 \\
(0.021)\end{array}$ & $\begin{array}{c}-0.024 \\
(0.019)\end{array}$ & $\begin{array}{c}-0.027 \\
(0.069)\end{array}$ & $\begin{array}{l}-0.058 \\
(0.077)\end{array}$ & $\begin{array}{l}-0.015 \\
(0.014)\end{array}$ & $\begin{array}{l}-0.039 \\
(0.053)\end{array}$ \\
\hline $\operatorname{PXS}(\mathrm{T}=5)$ & $\begin{array}{c}-0.008 \\
(0.011)\end{array}$ & $\begin{array}{c}-0.113^{* * *} \\
(0.037)\end{array}$ & $\begin{array}{l}-0.019 \\
(0.016)\end{array}$ & $\begin{array}{c}0.126^{*} \\
(0.069)\end{array}$ & $\begin{array}{c}-0.094^{* * *} \\
(0.035)\end{array}$ & $\begin{array}{l}-0.350 \\
(0.279)\end{array}$ & $\begin{array}{l}-0.001 \\
(0.018)\end{array}$ & $\begin{array}{c}-0.033 \\
(0.026)\end{array}$ & $\begin{array}{c}-0.041 \\
(0.034)\end{array}$ & $\begin{array}{c}-0.161^{* * *} \\
(0.057)\end{array}$ & $\begin{array}{l}-0.013 \\
(0.015)\end{array}$ & $\begin{array}{c}-0.098^{* * *} \\
(0.035)\end{array}$ \\
\hline $\operatorname{PXS}(\mathrm{T}>5)$ & $\begin{array}{c}0.007 \\
(0.006)\end{array}$ & $\begin{array}{c}-0.002 \\
(0.021)\end{array}$ & $\begin{array}{c}0.004 \\
(0.008)\end{array}$ & $\begin{array}{c}-0.015 \\
(0.067)\end{array}$ & $\begin{array}{c}0.013 \\
(0.018)\end{array}$ & $\begin{array}{c}-0.302^{* * *} \\
(0.117)\end{array}$ & $\begin{array}{c}0.007 \\
(0.012)\end{array}$ & $\begin{array}{c}0.014 \\
(0.014)\end{array}$ & $\begin{array}{l}-0.051^{*} \\
(0.027)\end{array}$ & $\begin{array}{l}0.053^{* *} \\
(0.026)\end{array}$ & $\begin{array}{c}0.011 \\
(0.009)\end{array}$ & $\begin{array}{l}-0.004 \\
(0.019)\end{array}$ \\
\hline Sample & $\begin{array}{l}\text { with } \\
\text { China }\end{array}$ & $\begin{array}{l}\text { with } \\
\text { China }\end{array}$ & WTO & $\begin{array}{l}\text { non- } \\
\text { WTO }\end{array}$ & WTO & $\begin{array}{l}\text { non- } \\
\text { WTO }\end{array}$ & $\begin{array}{c}\text { Low } \\
\text { income }\end{array}$ & $\begin{array}{c}\text { Low } \\
\text { income }\end{array}$ & $\begin{array}{c}\text { High } \\
\text { income }\end{array}$ & $\begin{array}{c}\text { High } \\
\text { income }\end{array}$ & $\begin{array}{c}\text { No } \\
\text { Africa }\end{array}$ & $\begin{array}{c}\text { No } \\
\text { Africa }\end{array}$ \\
\hline $\mathrm{N}$ & 52438 & 52,426 & 47,925 & 3,374 & 47,915 & 3,372 & 29,408 & 20,990 & 29,398 & 20,988 & 51,299 & 51,287 \\
\hline
\end{tabular}


Table 1A. Relationship between changes in the export elasticities and changes in preferential export shares

Dependent variable: Change in the average partner's preferential export share between 1988-2001 and 2002-2011 for:

All FTAs $\quad$ FTAs formed in 2001-2002

\begin{tabular}{lcccccc} 
& $(1)$ & $(2)$ & $(3)$ & $(4)$ & $(5)$ & $(5)$ \\
\hline \multirow{2}{*}{$\Delta$ Inverse exp. elast. } & $-0.038^{* *}$ & $-0.037^{* *}$ & $-0.027^{* *}$ & $-0.006^{* * *}$ & $-0.008^{* * *}$ & $-0.006^{* * *}$ \\
& $(0.017)$ & $(0.017)$ & $(0.012)$ & $(0.002)$ & $(0.002)$ & $(0.002)$ \\
\hline Industry FE & NO & YES & YES & NO & YES & YES \\
Country FE & NO & NO & YES & NO & NO & YES \\
R-squared & 0.001 & 0.137 & 0.320 & 0.001 & 0.090 & 0.254 \\
$\mathrm{~N}$ & 4,785 & 4,785 & 4,785 & 4,785 & 4,785 & 4,785 \\
\hline
\end{tabular}

Notes: ${ }^{*}$ significant at $10 \%,{ }^{* *}$ significant at $5 \%,{ }^{* * *}$ significant at $1 \%$. Standard errors are clustered by country. 


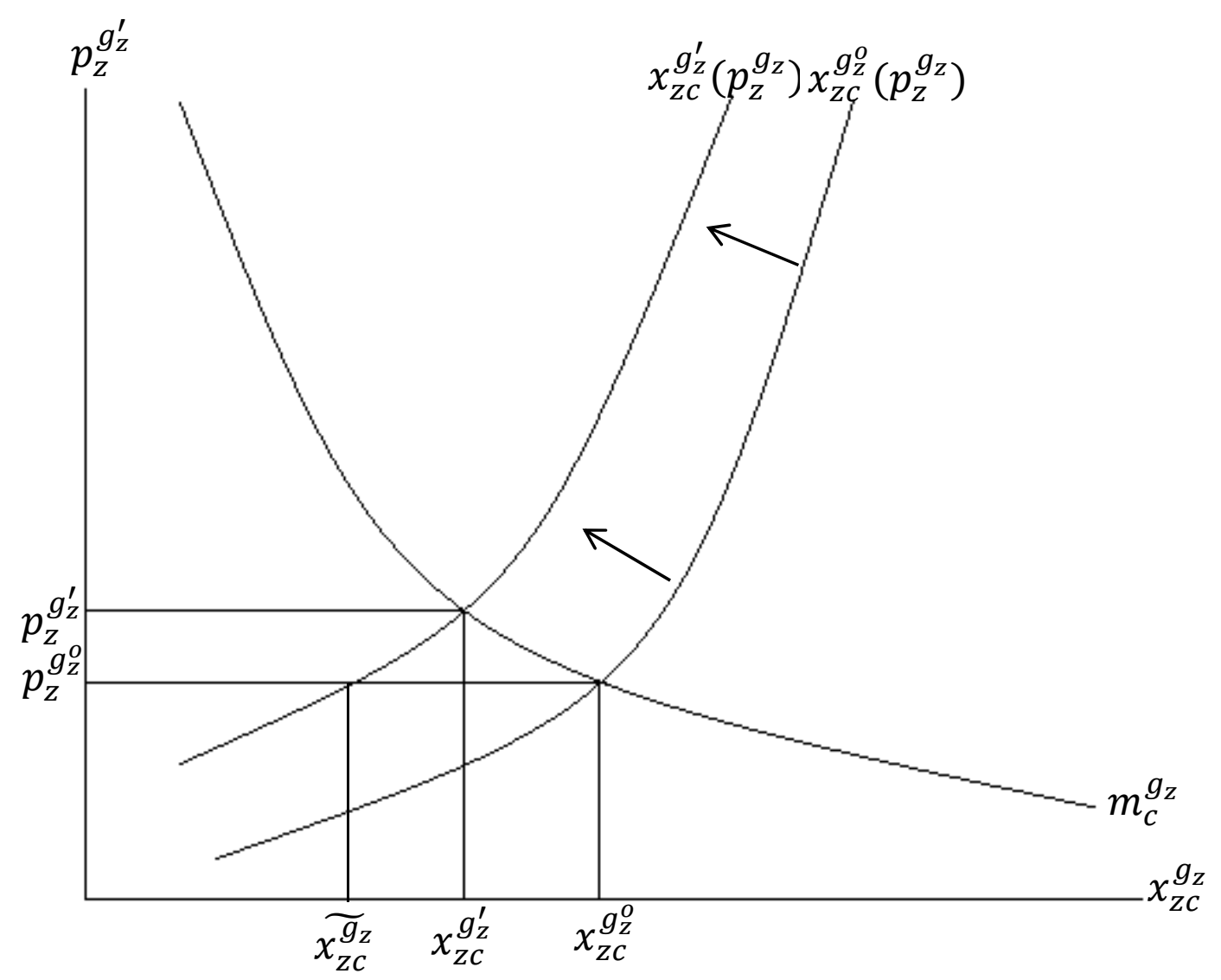

Figure 1: Strictly convex export supply function and external trade diversion 